Article

\title{
Assessment of Sustainable Development Goals (SDG) Implementation in Bulgaria and Future Developments
}

\author{
George H. Ionescu ${ }^{1, *(1)}$, Elena Jianu ${ }^{2}$, Ioana C. Patrichi ${ }^{3}{ }^{\circ}$, Florin Ghiocel ${ }^{4}$, Lili Țenea ${ }^{4}$ and Delia Iancu ${ }^{4}$ \\ 1 Department of Finance, Credit and Accounting, Romanian-American University, 012101 Bucharest, Romania \\ 2 Department of Finance, Accounting and Economics, University of Pitești, 110040 Pitești, Romania; \\ elena@eltralogis.com \\ 3 Department of Commerce, Economic Integration and Business Administration, Romanian-American \\ University, 012101 Bucharest, Romania; patrichi.ioana.cristina@profesor.rau.ro \\ 4 Department of Economics, Accounting and International Affairs, University of Craiova, 200585 Craiova, \\ Romania; floghi@yahoo.com (F.G.); tenea1964@gmail.com (L.T.); iancu.delia@ucv.ro (D.I.) \\ * Correspondence: george.ionescu@profesor.rau.ro
}

Citation: Ionescu, G.H.; Jianu, E.; Patrichi, I.C.; Ghiocel, F.; Țenea, L.; Iancu, D. Assessment of Sustainable Development Goals (SDG) Implementation in Bulgaria and Future Developments. Sustainability 2021, 13, 12000. https://doi.org/ $10.3390 /$ su132112000

Academic Editor: Antonis A. Zorpas

Received: 22 September 2021

Accepted: 28 October 2021

Published: 29 October 2021

Publisher's Note: MDPI stays neutral with regard to jurisdictional claims in published maps and institutional affiliations.

Copyright: (c) 2021 by the authors. Licensee MDPI, Basel, Switzerland. This article is an open access article distributed under the terms and conditions of the Creative Commons Attribution (CC BY) license (https:/ / creativecommons.org/licenses/by/ $4.0 /)$.

\begin{abstract}
The European Union has taken on the role of global leader in implementing the Sustainable Development Goals set out in the 2030 Agenda for Sustainable Development, making substantial efforts to support this ambitious approach at the level of each Member State. The objective of this research is the assessment of Sustainable Development Goals (SDG) implementation in Bulgaria as well as the existing development potential, given the existing knowledge gap related to this important topic. The data available on Eurostat were processed using dynamic indices and time series analysis based on ARIMA methodology in order to identify the evolution trend of the main indicators associated with the SDGs, as well as the dynamics of progress. The results obtained estimate, for 2030, a degree of fulfillment of the assumed targets of $36.28 \%$, but also reveal the existence of high potential for accelerating the transition process to a low-carbon economy and a more sustainable and inclusive society.
\end{abstract}

Keywords: sustainable development; 2030 Agenda; sustainable development goals (SDG); Bulgaria; SDG indicators

\section{Introduction}

The implementation of the Sustainable Development Goals has been and continues to be a major strategic priority for all EU countries, without which the world would have no chance of long-term survival. The reality of the days we are going through, unfortunately, shows the major need to make the planet and the actions of people, companies, and governments much more sustainable, so that any other future changes/dangers will find us in a state of equilibrium in terms of the view of the resource-people-quality-of-life relationship.

The COVID-19 pandemic and the severe climatic imbalances produced especially in the current year have stimulated to an even greater extent all the governments of the world and all the actions of political, social, and economic bodies to move to rapid, profound measures for present and future society to ensure basic conditions of sustainable living, in relation to the challenges we still identify in everyday life, namely technology and computerization, depleted resources, climate change, increased pollution, serious social disparities, and multiple imbalances in relation to the environment and its resources.

Based on these general considerations, the aim of this paper is to identify the current state of affairs in which countries such as Bulgaria, a developing European state, find themselves in, in the face of the long-term goals of sustainable economic growth.

The 2030 Agenda [1] is certainly a national priority for this country as well, but the way in which sustainable objectives have been implemented at all levels of economic and 
social life continues to be a challenge for the Bulgarian government, for all political and economic entities, and, not in least importance, for people.

In order to assess the state of achievement of the SDGs in Bulgaria, we conducted extensive research of all indicators related to the 17 Sustainable Development Goals (SDGs) and their related 169 targets, based on data published by Eurostat and assumed by the UN's 2030 Agenda for Sustainable Development. The analysis was performed based on the dynamic indices, and the forecast of the evolution of the indicators for the 2030 Horizon was based on the ARIMA methodology.

To be or not to be sustainable today, in relation to the goals of the 2030 Agenda, are answers that Bulgaria, through measures and actions taken over time, seeks, identifies, and further corrects so that the future is a safe one for society but also for the national economy $[2,3]$.

To address these challenges, Bulgaria has created the specific institutional and organizational framework and allocated financial resources to respond to strategies resulting from international cooperation for sustainable growth, even though financial allocations for development are still below $0.11 \%$ of gross national income (GNI), unfortunately far from the EU commitment of $0.33 \%$ [2].

We also identify a number of negative issues that support the idea that Bulgaria will not be able to meet the Sustainable Development Goals for a number of targets, such as migration. From this point of view, Bulgaria is still in one of the last places in the EU in terms of reaching the targets for 2030; in 2019 (for example), being ranked 26th out of 28 Member States [4]. This low performance is mainly focused on migration and mobility in particular, but even in this context Bulgaria has a significant potential to correct various negative situations, with at least a political desire to catch up with other EU Member States $[4,5]$.

Although there are a number of concrete measures and actions taken by Bulgaria, we still identify a lack of information promoted by the bodies involved in the implementation and monitoring of the SDG according to the 2030 Agenda, the only monitoring report published on the Bulgarian Development Platform for 2020. Bulgaria has seen progress in achieving only 3 of the 17 SDGs, namely SDG 4, SDG 8, and SDG 10 [4].

In conclusion, we note that Bulgaria has failed in all situations to create and promote models of prosperity and sustainability, so that the objectives of the 2030 Agenda are met. Therefore, the development of a long-term vision, based on inclusive growth and on the cohesion of Bulgarian society, can eliminate the phenomenon of deep and persistent poverty in this country. To this end, it is essential to analyze the shortcomings of policy measures and to look for appropriate ways to achieve real results in poverty reduction. We believe that this study can bring new knowledge about the potential achievement of the SDG targets proposed by Bulgaria, the research results contributing significantly to drawing a more complete picture of the sustainable development potential of Bulgaria.

This paper is divided into five sections. Following the introduction, Section 2 presents a brief review of the SDG's status in Bulgaria, Section 3 describes the research methodology, Section 4 presents the main findings of the study, and Section 5 aggregates the conclusions of the research.

\section{Review of the SDG's Status in Bulgaria}

SDG 1-No poverty. Bulgaria still has a number of disparities in terms of the territorial distribution of poverty, inequalities between cities and villages, and differences between territorial regions, even if government spending on social protection (for example) amounts to $12.6 \%$ of GDP on average in the last 10 years [6].

Although national legislation provides that all people have equal access to social assistance, Bulgaria has a number of relatively negative specific issues, such as the fact that most older people live in rural areas, which limits their access to health services and social services [7]. 
On the other hand, we identify an increase in the minimum wage, a measure imposed in particular by the international labor standards established in this field (Convention on the Establishment of the Minimum Wage No. 131 of the International Labor Organization of 1970), to which Bulgaria acceded only in 2018 [2].

A consequence of this legislative act is the increase of the minimum wage to EUR 311.89 for 2020 , with an increase of $8.9 \%$ compared to the previous minimum wage, which generated a percentage of $68 \%$ of the population above the poverty line [2]. The chain effects of this legislative result are obvious and have multiple effects, mainly contributing to the increase of labor force motivation to remain in the internal labor market, to the increase of the living standard, but also to the reduction of the poverty index.

Regarding the social protection system, the data for 2018 show that the relative share of the poor has decreased from $23.4 \%$ to $22.0 \%$ [2]. Even though new measures have been implemented in the meantime to reduce this negative phenomenon (such as increasing the minimum pension by $5.7 \%$ in 2019 compared to 2018), the poverty and social exclusion rate in Bulgaria remains the highest among EU Member States [6].

For 2020, the Bulgarian National Institute of Statistics stated that the size of the poverty line had increased by 9.2 percent and the relative share of the poor by 1.2 percentage points as the pandemic put more people at risk of poverty in 2020, a year in which $19.4 \%$ of the population faced real material deprivation. Moreover, in 2019, the poor in Bulgaria numbered 1.586 million people or $22.6 \%$ of the population $[2,8]$.

In all these respects, the socioeconomic consequences of COVID-19 are becoming increasingly evident. In this regard, we highlight the Alpha Research survey, according to which the economic sectors in Bulgaria were affected differently depending on the quarantine measures; there are sociodemographic groups that have become unemployed (lost their jobs due to the crisis), in addition to the previously unemployed. In total, these groups that have suffered the most significant decline in income represent about a quarter of the Bulgarian population. The same survey identifies three main sources of unemployment: layoffs after the closure of companies as a result of emergency measures $(56 \%$ of the unemployed), layoffs in industries whose activity has declined with the slowdown in the activities of companies withpartners abroad (32\%), and people who returned from abroad due to job loss there (12\%). Moreover, according to a survey conducted by Gallup International, due to quarantine, in May 2020,15\% of Bulgarians had problems with access to healthcare and $28 \%$ with the supply of medicines and consumables [9].

SDG 2-Zero hunger. For Bulgaria, the implementation of SDG 2 aims to ensure a high level of health protection through a series of measures that are reflected in the results achieved over the years. Therefore, ensuring food security and eliminating nutrition problems, especially among children, which is accompanied by the stimulation of organic farming, are directions of action that have been considered by the local government. These directions have visible results, especially at the level of legislation which concerns agriculture, depopulation of rural areas, stimulation of green entrepreneurship in rural areas, and ensuring the conditions for harmonization of entrances and exits in rural destinations/regions.

Bulgaria's situation must also be viewed from many other perspectives, including the implications of the pandemic for all aspects of life, as it shows an uncertain path in the future, which requires a correct approach and management of this crisis $[10,11]$.

In this sense, we highlight the strategy for the digitization of agriculture but also of rural areas with targets until 2027, to which is added the specific legislation for the support of farmers through the Rural Development Program, 2007-2013 and 2014-2020. We also identify a number of research activities with direct results in product certification, as well as local civil initiatives aimed at the sustainable use of grasslands. Business incubators were also promoted and a number of business models for innovation, entrepreneurship, and resilience in European agriculture (NEWBIE) were selected and funded through specific programs, such as Horizon 2020. 
SDG 3-Good health and wellbeing. Bulgaria has seen a great change in the health of the population over the last three decades, even though there have been visible improvements in the last 10 years. The country continues to face many challenges in this regard and although it has seen a number of improvements for most of the 19 core health policy indicators, there are unfavorable trends for a large number of indicators, such as: smoking, pure alcohol consumption, and the prevalence of overweight and obesity [12-14].

Bulgaria's spending on education, health, and welfare services remains low and there is still room for growth. Therefore, the increase in public spending becomes very important for the future of Bulgaria in terms of improving all social aspects. We support this due to the fact that Bulgaria is facing an aging population, and spending on pensions and health is essential as it directly contributes to improving the process of inclusion and sustainable growth. In fact, pensions already provide income for a share of about $40 \%$ of the population and unfortunately estimates show that the number of pensioners is growing rapidly, a situation generated by the withdrawal from the labor market of the "baby boom" generation [15].

Therefore, it appears to be a pressing need for Bulgaria to implement health support measures, as an increase in the demand for long-term health care is expected, as these services increase sharply with age and beyond [11]. The provision of high-quality, long-term preventive health services, while ensuring sustainable funding, also requires appropriate financial legislation to ensure synergy between the health care system, the prevention system, and quality of life [15].

SDG 4-Quality education. From an education perspective, Bulgaria has one of the most inequitable education systems in the EU, and significant efforts are still needed to implement new reforms and create real opportunities for at least $40 \%$ of the population.

The level of education in Bulgaria is deficient. INS data in 2018 show that $31.6 \%$ of employees had higher education, $57.2 \%$ had secondary education, and only $9.5 \%$ had primary education [2].

In this context, the "Strategy for the Development of Higher Education in the Republic of Bulgaria for 2021-2030" is a response to the challenges facing the Bulgarian education system, which seeks to identify appropriate solutions to provide graduates with specific skills and competences in the labor market; information and knowledge must be upgraded to face new economic, social, and environmental challenges [16,17].

We also continue to identify a number of shortcomings for Bulgaria in terms of: improving student outcomes; access to education for children from poor families; and improving access to primary and secondary education, adult education and continuing education, especially for vulnerable groups, low-skilled, marginalized groups with the lowest level of formal education and the lowest level of literacy [18].

School dropout is also one of the serious problems which faced Bulgaria in 2019 [2]; for example, the largest share of those who dropped out of school before the seventh grade is represented by those who went abroad $(48 \%)$, followed by those who left for family reasons $(39 \%)$.

The strategy of educational integration of children from ethnic minorities, 2015-2020, is one of the concrete actions of the Bulgarian government, but public investments are what will make the difference in the future, knowing that in this country a number of negative situations predominate, such as an overall rate of accounting irregularities (60\% of audited tenders related to the use of EU funds, according to the 2011 report). The 2016 CVM report also indicated that compared to other EU Member States, the European Anti-Fraud Office has a relatively large number of ongoing investigations for Bulgaria related to the use of EU funds. These cases are mainly related to corruption, irregularities, but also fraud in public procurement by public authorities [18].

However, there are concerns at the government level about the coherence of education programs, which are indispensable for improving the quality of life of Bulgarian citizens, as curricular relevance in a global, European context is becoming a constant challenge. For this major positive step, substantial financial support is needed to strengthen public 
institutions, in order to increase opportunities for public-private partnerships, increase the skills of the elderly, and provide effective lifelong learning opportunities [19].

Moreover, large-scale interventions at all levels of the education system, as well as for the qualification and requalification system, must be focused in particular on the digital competences of human capital. The measures are aimed in particular at young people, the unemployed and economically inactive and disadvantaged groups. A key tool in developing the digital skills needed by the population will be the development of partnerships with the private sector, based on the good practices of the Ministry of Education and Science and the IT Career Education Program.

SDG 5-Gender equality. Bulgaria has a long history of gender equality legislation, dating back to the end of the 19th century, focusing mainly on the equal rights of Bulgarian women to inheritance but also on the equal duration of high school education with men. Since the 1900s, the field of gender equality has expanded to include the unrestricted right of married women to enter business, the regulation of divorce, and access to university education [20].

At present, Bulgarian law guarantees gender equality in all spheres of social, political, and economic life. It is currently found in the Bulgarian Legislation-Constitution of the Republic of Bulgaria as well as in a number of special laws. The principle of nondiscrimination is also present in all relevant legislation.

Bulgaria ranked 18th in 2018 among 149 countries, according to the Global Gender Gap Index, while according to the World Bank's "Women, Business and the Law" Report 2019: "A Decade of Reforms", Bulgaria had one of the leading positions on gender equality, with index 93.75 out of 100 .

Bulgaria also has the leading position in Europe in terms of the number of women working in the IT sector-27\% (17.2\% in the EU); women among scientists and engineers account for $53 \%$, and the proportion of women with education is higher than that of men in all age groups except those over 65 years of age. In 2019,39.1\% of the members of the Council of Ministers and $14 \%$ of the mayors were women. The president of the National Assembly and the mayor of the capital were women. At the same time, according to the European Institute for Gender Equality, in 2019, Bulgaria ranked sixth in the EU in terms of gender equality in power [21].

We also mention that in Bulgaria, 30\% of technology and communication employees are women, which draws attention to the implementation of new measures to balance the gender ratio. It is also important to note the issue of violence against women, common in Bulgaria in 2018; for example, 371 girls aged 14-17 were victims of crime [22]. Trafficking in human beings is also a common problem among women, who are especially abused by compatriots in the poor economic regions of the country and where, unfortunately, there are few job opportunities.

There are also a number of issues that put Bulgaria in a good position in various gender equality rankings, such as: $53 \%$ of scientists are women, the proportion of women with higher education is higher than that of men, in 2019,39.1\% of the members of the Council of Ministers were women, and $14 \%$ of the mayors were women. Moreover, according to the European Institute for Gender Equality, in 2019, Bulgaria ranked sixth in the EU in terms of gender equality in management, and in 2018, 26.7\% of employers were women [21].

SDG 6-Clean water and sanitation. Water and sewerage services are an increasingly acute issue for Bulgaria in terms of management, control, and regulation. Although the regulation of water quality and the prices of water and sewerage services has been implemented in Bulgaria for the last 15 years, this has been done poorly, which is why there are still challenges in finding solutions for the future. Therefore, regulators need to focus on providing management adapted to the new challenges posed by the complex, multiple changes that Bulgarian society must respond to $[23,24]$.

Currently, in Bulgaria, we identify the Management and Development Strategy of the water supply and sewerage sector, including regional plans for water supply and sewerage for the periods: 2014-2020, 2021-2028, and 2029-2038. 
Moreover, in order to restore ecological balance, especially in wetlands, we also identify the "National Action Plan for the Conservation of Wetlands of High Significance in Bulgaria (2013-2022)", which covers 11 wetlands. We also note in this objective of sustainable development the national strategy for Roma integration in the Republic of Bulgaria (2012-2020) which aimed at building infrastructure for water supply, sanitation, street network and rehabilitation, etc. in Roma communities [25].

SDG 7-Affordable and clean energy. The multiple, positive effects of the transition to renewable energy have led to a reorientation of long-term sustainable development strategies for all EU Member States and beyond. In this context, Bulgaria, the EU's poorest state, has already reached its 2020 renewable energy targets. This result contradicts the hypothesis that poorer countries are more likely to fail to meet environmental targets [26-28].

In Bulgaria, the policy of creating a sustainable environment but also the implementation of measures for the competitive energy market is visible, with positive results in multiple economic sectors. This result is also a consequence of the fact that 25 Bulgarian municipalities have joined the European Covenant of Mayors, which involves local and regional authorities in the process of using energy from renewable sources. Thus, $100 \%$ of the Bulgarian population has access to electricity and $18 \%$ have access to renewable energy. Therefore, according to the annual assessments, Bulgaria's energy efficiency is 6 points, with an average overall rating of 5.27 points. On the other hand, Bulgaria's economic growth also led to an increase in primary energy consumption, which is on the rise, with high energy intensity of EUR $426.18 \mathrm{~kg} /$ EUR 1000. This aspect generates competitiveness in the economy over time [2,29].

Bulgaria's energy dependence is lower than that of many European countries ( $36.5 \%$ in 2018 according to Eurostat data). Unfortunately, the energy sector also generates most of its total greenhouse gas emissions, contributing to over $90 \%$ of the sector's greenhouse gas emissions, a trend that has remained relatively constant over the last two decades. We also note that there is an increase in the share of electricity from renewable sources in gross final consumption of electricity, from $12.4 \%$ in 2010 to $22.2 \%$ in 2018, but also in the consumption of fuels used in transport, from $1.4 \%$ in 2010 to $8.1 \%$ in 2018 [22,30].

SDG 8-Decent work and economic growth. Achieving sustainable economic growth and productive employment is one of the main goals of sustainable development in Bulgaria. Currently, there are a number of difficulties, especially in rural areas, which are slow to move towards achieving sustainable growth goals. Unfortunately, more than $1 / 2$ of Bulgaria's rural population is at risk of poverty or social exclusion, which is why Bulgaria ranks first in the EU in relation to this indicator [31].

On the other hand, Bulgaria, like all EU Member States, has implemented a number of measures that promote sustainable economic growth, growth supported mainly by exports. Therefore, for the period 2014-2019, Bulgaria's economic growth rate remained relatively stable at around 3\%, and from the perspective of the 2017-2018 competitiveness report of the World Economic Forum it ranked 25th in the world and 11th in the EU.

Bulgaria is also, like many Eastern European countries, one of the most attractive countries in terms of foreign investment, being attractive at least in terms of the lowest percentage of income tax in Europe. This favors Bulgaria in the long run, as it represents high interest for investments in industry and services, aspects that generate GDP growth, with a $2.5 \%$ average rate of FDI to GDP [22].

On the other hand, we identify a number of problems related to the reduction of the demographic replacement rate, a problem again specific to the Eastern European states, caused by the phenomenon of emigration of active people in the labor market, but also by the aging of the labor force. This adds a negative natural increase of $6.5 \%$. However, we identify a high share of the unemployed among young people in the context in which, for example, only $12 \%$ of young people without education, aged between 15 and 24 , enrolled in the training program "Youth Guarantee" [2].

All these aspects create a series of long-term economic imbalances, which pose a number of challenges for the Bulgarian government, with an increase in regional disparities 
in terms of economic development from one year to the next. Severen Region (Northwest) being, for example, the least developed [32].

An important aspect to mention for the Bulgarian economy is the fact that we identify an important activity but also high investments in the tourism sector, which generates on average $11 \%$ of GDP and about $11 \%$ of the employed population, except for the period 2020 affected by the COVID-19 pandemic, the period that mainly affected those whose economy is based on tourism and services adjacent to it. In fact, Bulgaria's economy is mainly based on small and medium-sized companies, which are the basic structure of the economy, but also the main source of active employment [22,33-35].

SDG 9-Industry, innovation, and infrastructure. As with all EU Member States and Bulgaria, sustainable development has as its central objective the creation of an infrastructure for industry and all other innovative areas of activity that supports the economy, society, and the environment in a harmonious and balanced way in the long term.

Therefore, the synergy between all actors involved, political, economic, and social, must pursue the same goal, take action for the same goal, and stimulate innovation for the same goal, namely sustainable development, in line with the targets set for 2030 . We note that Bulgaria ranks 37th in the world according to the Global Innovation Index, 19th in the efficiency of innovation in 2018. Obviously, all these objectives depend to a large extent on the financial support of European programs, which need to be directed only towards sustainable economies and which bring long-term competitive advantages to Bulgaria [36].

An important aspect to mention is the fact that Bulgarian mechanical and electrical engineering is very competitive globally, but this sector is dominated by about $30 \%$ of employees of retirement age. On the other hand, the share of people with basic digital skills is about $29 \%$ of the Bulgarian population, which over time can cause real problems for Bulgaria in the European and global market. This is also the reason why it is necessary to accelerate the measures to implement the new digital skills for the active workforce, but also for those who will enter the labor market, because the digitalization of the economy is one of the chances that the world's economies have at their disposal to combat a number of negative effects caused in particular by climate change [37,38].

We identify in this regard the national program "Digital Bulgaria 2025" which aims at inclusive and sustainable digital growth for the period 2018-2025, the government's priorities including stimulating growth through high-tech industrialization, the only one that will create added value in the future. In addition, in terms of infrastructure, Bulgaria has expanded its road network with EU funds, with more than $300 \mathrm{~km}$ of new sections of motorway.

The EU is also investing EUR 293.4 million through the Cohesion Fund in a modern railway between the cities of Plovdiv and Burgas, connecting some of Bulgaria's largest cities to one of the most important ports on the Black Sea. "BDZ-Tovarni Prevozi" EOOD (BDZ Cargo).

At the same time, in Bulgaria, the share of the ICT sector in the formation of GVA is relatively high, ranking 5 th in the EU, but there is also an increase in exports in this respect, high-tech products being $7.2 \%$ in export production, at the level of 2017 , even if the use of the internet is lower than the EU average [2].

SDG 10-Reduced inequalities. Reducing social inequalities is also a strategic national priority for Bulgaria, which is one of the strategies directly dependent on all the other SDGs proposed in the 2030 Agenda. However, Bulgaria is one of the countries where inequalities generate major long-term socioeconomic disadvantages, which means it has to overcome a series of challenges, especially the ones related to income, respectively, to reduce the ratio between the poorest (20\%) and the richest (20\%) [39].

Significant differences continue to prevail between the incomes of the poor regions, especially those in rural areas, and in terms of the situation in cities and regions with relatively stable economic growth (Sofia/ Stara Zagora, Bulgaria); we still identify an increase of inequalities generated by rising incomes of only a small part of the population. 
Obviously, the inequalities are reflected by a series of other statistical data that refer to unemployment, access to education and information, medical assistance, and pregnancy situations, especially at the level of rural areas/communities and at the level of the Roma community. An example of this is the growing pressure on public finances in Bulgaria generated by the need to implement a performance-based public funding system for higher education. This aspect is all the more important in the context in which there is a direct relationship between various profiles of migrants and their level of education or their position in society $[40,41]$.

SDG 11-Sustainable cities and communities. From the perspective of the implementation of SDG 11, we highlight the fact that the countries of Central and Eastern Europe (EEC) have been directly involved in the implementation of the legal and institutional framework for sustainable growth and sustainable development of the economy and society. Even under these conditions, there are a number of negative phenomena in these countries, such as declining production and rising unemployment, pollution, real discrepancies between urban and rural areas, etc., although the "Europe 2020" strategy for smart and inclusive sustainable growth has offered multiple funding opportunities. Sustainability issues in Central and Eastern European cities, in this case also in Bulgaria, call for special emphasis on policies capable of creating synergies between smart urban development and sustainable development. We are still looking for smart policies that rationally combine knowledgebased investment in areas with competitive advantages and coherent support measures for a greener economy, as a precondition for the territorial cohesion and competitiveness of all EU Member States [42,43].

Not to be neglected in this context is the role of sustainable development of rural communities, by developing and implementing new methods and tools for synergy of urban and rural communities. It is thus necessary for Bulgaria to have a management model based on permanent communication and feedback for the promotion and implementation of the concept of corporate social responsibility at the level of all urban and rural communities [44].

For Bulgaria, in the current context of constant actions to implement sustainable strategies in order to achieve the goals of the 2030 Agenda, transforming cities into sustainable communities is a real long-term challenge. Currently, European-funded projects are being implemented for the development of a balanced polycentric network of urban localities. Thirty-nine cities in the country have received European financial support, as well as a number of projects related to improving living conditions, improving housing, creating a sustainable transport infrastructure, creating green spaces, sports and recreation, etc.

However, cities in Bulgaria were built for a much smaller population than today $(73.7 \%$ of Bulgaria's population lived in cities), thus increasing the phenomenon of urbanization after the second half of the 20th century; this is an issue that has greatly aggravated the sustainability of large cities in particular. For example, in Sofia, the population has grown from about 0.5 million citizens in 1946 to about 1.3 million citizens today, which generates an increasing degree of risk in terms of air pollution, pollution that must be reduced to the limits that allow a good state of human health [22].

Therefore, it is a priority to change approaches to sustainable development of urban and rural communities by implementing them in research and innovation strategies for smart specialization, for good incorporation of the objectives of the 2030 Agenda. "Smart communities" serve as an effective engine for a new development trajectory for European regions that are lagging behind in implementing the 2030 Agenda. Bulgaria is one such example [45].

SDG 12-Responsible consumption and production. From the point of view of sustainable consumption, we identify the fact that Bulgaria has included in its legislation European norms on both environmental protection and legislative elements on consumer protection, waste management, etc. This is a consequence of the fact that the European Environment Agency constantly warns that Europe consumes too many resources and causes environmental degradation to a very large extent [46].

It is therefore necessary for each state, including Bulgaria, to design and promote urban environmental concepts in order to increase young people's sensitivity to sustainability 
through responsible consumption and to encourage them to consume environmentally friendly alternatives to everyday goods and services. An approach to the implementation of these projects in Bulgaria can be based on information on the impact of consumption on the environment, combined with motivational activities, in order to change attitudes and encourage young people to adopt green lifestyles [47,48].

This is because there are still a number of negative issues that require the legislature to take much more intense measures to achieve a responsible balance between consumption and resources. We bring, in this sense, the example of the survey conducted by BFB in 2017, which specifies that over 670 thousand tons of food per year are destroyed in Bulgaria, of which $44 \%$ came from households, $33 \%$ from restaurants, and from shops, $11 \%$, which is why the European Commission (2019) pointed out that Bulgaria lost an average of EUR 63 million, a loss explained by insufficient waste recycling, plus a loss of benefits of EUR 53 million. Obviously, all these negative elements identified in Bulgaria remain noteworthy because the situation of hazardous waste generated affects the environment in the long run, pollution, or climate change [46].

However, we identify in Bulgaria a number of strategies for the transition to the green economy, the circular economy, such as the 2021-2027 program, which can facilitate the achievement of competitive advantages and the approach of the targets set for 2030.

We also identify measures to stimulate the green economy, such as: redistribution of edible food to those in need and tax cuts for food donors, joined by pollution measures, such as the Local Taxes and Taxes Act, 2018, for determining the vehicle tax.

SDG 13-Climate action. Although Bulgaria has implemented all international agreements on climate agreements, there are a number of challenges related to climate change. This is because Bulgaria is in a region with a changing climate, as are all the countries in Southeast Europe, especially in terms of rising temperatures in all seasons [49].

Natural threats, forest fires, floods/droughts, extreme temperatures, etc., have negative economic effects on the country. For example, the damage caused by events such as fires, floods, etc., for the period 2010-2018 amounts to almost EUR 880 million. Thus, more than EUR 640 million was allocated for restoration, while more than EUR 102 million was used for rescue and emergency operations [22].

Bulgaria is a party to the United Nations Framework Convention on Climate Change, has signed the Paris Agreement, and is involved in projects to achieve the overall goal of reducing greenhouse gases. At the national level, a number of actions/plans are aimed at achieving a set of targets set by the 2030 Agenda for the most important sectors of the economy (agriculture, biodiversity and ecosystems, energy, forests, health, transport, tourism, urban environment, and water).

SDG 14-Life below water. For Bulgaria, this objective is mainly aimed at the Black Sea ecosystem. Unfortunately, at present, the Black Sea's ability to recover from overexploitation is close to its critical limit. The Black Sea is the only sea in the EU for which no EU strategy has been adopted. Among the main challenges for the Black Sea ecosystem are mainly the chaotic constructions on the coastal area.

Pollution is also higher than in the Mediterranean Sea, as rivers flowing into the Black Sea are rich in organic matter, nitrogen and phosphorus compounds, heavy metals, and sewage waste. The challenge is also generated by the fact that not all neighboring countries are bound by EU rules, therefore, about 350 cubic $\mathrm{km}$ of water/year, from rivers in more than twenty countries, flows into the Black Sea, this being a huge catchment. Wastewater is generated by over 162 million people. The pollution is accentuated by intense maritime transport but also by activities related to the exploitation of oil and natural gas [50].

According to the National Environmental Monitoring System (NSEM), progress in sea quality is slow, no type of water meets the objectives of the EU Framework Directive on surface water status, and the coastal area in the Gulf of Varna is even more problematic. Moreover, with the expansion of the hotel infrastructure in the Bulgarian coastal area, the problems of overuse of communal and utilitarian infrastructure, transport infrastructure, and environmental pollution have intensified [2,51]. 
SDG 15-Life on land. Although Bulgaria has rich biodiversity and 1/3 of the country's surface is covered by forests, a negative situation is identified, as a whole, as they are located in one of the most affected regions, where there are a number of risks, such as, for example, soil degradation, increasing extreme phenomena, fires, or low rainfall. The erosion processes are manifested on approximately $85 \%$ of the soils in the country, aspects that generate in the medium and long term real causes for an ecological and environmental crisis $[52,53]$.

SDG 16-Peace, justice, and strong institutions. Even though Bulgaria is a European country, with a number of well-founded laws, a number of incidents related to trafficking in human beings are still identified. It is also a destination for crime. There is still a tendency for girls and women to be in most cases victims of human trafficking, which is joined by violence against children. The efficiency and transparency of the judiciary are also among the most serious problems facing Bulgaria [54].

SDG 17-Partnerships for the goals. From a partnership perspective, Bulgaria is responding to UN calls for solutions to reduce global challenges related to poverty, access to education, sustainable growth, environmental protection, water and energy management, and the building of democratic institutions in this regard.

Moreover, raising awareness of the management of Bulgarian organizations in the direction of sustainable actions remains a priority of the Bulgarian government and a continuing challenge.

However, there is no framework law for development policy for the creation of a coordination mechanism between the actors involved in development policy at the national level. Moreover, there is a lack of an administrative structure appropriate to Bulgaria's commitments at a European and global level [55].

\section{Research Methodology}

To assess the state of implementation of the SDG in Bulgaria, as well as to be able to analyze the potential future developments regarding the evolution of these indicators, we based our research on the latest data provided by Eurostat [6].

The analysis starts in 2015, the year in which the SDGs were adopted, in order to define a reporting basis for the analysis of the dynamics of evolution. In order to increase the relevance of the analysis and, respectively, the accuracy of the forecasts, the trend of the indicators was calculated based on the available data starting with 2007.

Dynamic indices refer to homogeneous phenomena, described by a single time series, and count the ratio between the size of an economic phenomenon analyzed between two different time periods. To estimate the dynamic indices [56-58], ratio between the indicator analyzed at a given time $\left(\mathrm{I}_{\mathrm{n}}\right)$ and the value of the respective indicator in the base period $\left(\mathrm{I}_{1}\right)$, has been calculated according to the Formula (1):

$$
\mathrm{I}_{\mathrm{n} / 1}=\frac{\mathrm{I}_{\mathrm{n}}}{\mathrm{I}_{1}} \times 100 \%
$$

where $I_{n}$ is the indicator value in a given moment and $I_{1}$ is the indicator value in a comparative period.

Time series analysis is based on the fact that data analyzed over time may have an internal structure (e.g., as autocorrelation, trend, or seasonal variation) that should be taken into account. The use of time series models aims, on the one hand, to obtain an understanding of the phenomena and structure that produced the observed data and, on the other hand, to identify an appropriate model for predicting the evolution of the analyzed phenomenon over time.

For the forecast of the data series specific to the indicators of each SDG, we resorted to the software package SPSS and ARIMA methodology, developed by Box and Jenkins [59-62], due to the power of prediction and the flexibility it shows.

The Box-Jenkins ARIMA model is a combination of autoregressive (AR) and moving average (MA) models. A common approach for modeling univariate time series is the 
autoregressive (AR) model. An autoregressive model is a linear regression of the current value of the series against one or more prior values of the series, while $p$ is the order of the AR model, as shown in Equation (2):

$$
X_{t}=\delta+\theta_{1} X_{t-1}+\theta_{2} X_{t-2}+\ldots+\theta_{p} X_{t-p}+\varepsilon_{t}
$$

where $X_{t}$ is the time series, $\varepsilon_{t}$ is white noise, and $\delta=\left(1-\sum_{i=1}^{p} \theta_{i}\right) \mu$, with $\mu$ denoting the process mean.

Another common approach for modeling univariate time series models is the moving average (MA) model. Such a model is based on linear regression of the current value of the series against the white noise or random shocks of one or more prior values of the series. The random shocks at each point are assumed to come from the same distribution, typically a normal distribution, following Equation (3):

$$
X_{t}=\mu+A_{t}-\theta_{1} A_{t-1}-\theta_{2} A_{t-2}-\ldots-\theta_{q} A_{t-q}
$$

where $X_{t}$ is the time series, $\mu$ is the mean of the series, $A_{t-i}$ are white noise terms, $\theta_{1}, \ldots$, $\theta_{q}$ are the parameters of the model, and the value of $q$ is the order of the MA model.

The SPSS software package allows one to estimate exponential smoothing, univariate or multivariate Autoregressive Integrated Moving Average (ARIMA) models, based on the best-fitting ARIMA model for one or more dependent variable series. This is denoted by ARIMA ( $\mathrm{A}, \mathrm{d}, \mathrm{q})$, where $\mathrm{p}$ is the order of autoregressive process, $\mathrm{d}$ is the order of differencing, and $\mathrm{q}$ is the order of moving average process.

For each SDG, all specific indicators for which there are valid published data were analyzed individually, both for Bulgaria and for the EU average. For each analyzed indicator according to the methodology described above, the values for 2020 (if there were no published data), 2025, and 2030 were forecasted; as well, for national indicators, the long-term trend and the possibility that in 2030 the values reach a value equal or better than the EU average were estimated.

\section{Results and Discussion}

In order to obtain a more accurate picture of the potential degree of achievement for the SDG-associated indicators, we used the tools described in the previous chapter to predict the evolution of the selected indicator values for the Horizon 2020-2030, based on available data starting with 2007, selecting three terminals that are important over time: 2020, 2025, and 2030.

Moreover, for an analysis of the dynamics of evolution, we calculated the dynamic indices based in 2015 for the years 2020, 2025, and 2030, the results providing a detailed picture of the rate differential adjustment of the differences between the value of indicators at the national level and the average value of indicators at the EU level.

A third stage consisted in estimating the long-term trend in which the analyzed indicators are likely to be included, the result adding more information on the general direction in which Bulgarian society is heading, but also on the convergence or divergence towards the trend of similar indicators calculated as the average of all 28 EU Member States. All relevant information is summarized, for each SDG, in Tables 2-18.

For a synthetic image of the general potential degree of reaching or exceeding the average value of the EU indicators estimated for 2030, we have summarized the main information in Table 1.

As can be seen, the forecasts indicate that it is very likely that Bulgaria will not reach the European average for any of the 17 SDGs by 2030, and for SDG4 and SDG5 it is estimated that none of the analyzed indicators will reach or exceed the European average. These results do not indicate that Bulgaria cannot meet the quantitative targets where they have been defined, but emphasize the additional need for involvement of all stakeholders to accelerate the convergence of national indicators towards the EU average. 
Table 1. Achieving the sustainable development goals in Bulgaria.

\begin{tabular}{|c|c|c|c|}
\hline Sustainable Development Goals & No. of Indicators & $\begin{array}{l}\text { No. of Indicators Forecast to Reach } \\
\text { the EU Average Value in } 2030\end{array}$ & Percentage of Achievement \\
\hline SDG 1-No poverty & 12 & 6 & $50.00 \%$ \\
\hline SDG 2-Zero hunger & 7 & 3 & $42.86 \%$ \\
\hline SDG 3-Good health and wellbeing & 11 & 5 & $45.45 \%$ \\
\hline SDG $4-$ Quality education & 6 & 0 & $0.00 \%$ \\
\hline SDG 5-Gender equality & 7 & 0 & $0.00 \%$ \\
\hline SDG 6-Clean water and sanitation & 7 & 5 & $71.43 \%$ \\
\hline SDG 7-Affordable and clean energy & 8 & 4 & $50.00 \%$ \\
\hline SDG 8-Decent work and economic growth & 9 & 2 & $22.22 \%$ \\
\hline SDG 9-Industry, innovation, and infrastructure & 7 & 1 & $14.29 \%$ \\
\hline SDG 10-Reduced inequalities & 10 & 2 & $20.00 \%$ \\
\hline SDG 11-Sustainable cities and communities & 10 & 6 & $60.00 \%$ \\
\hline SDG 12-Responsible consumption and production & 6 & 1 & $16.67 \%$ \\
\hline SDG $13-$ Climate action & 5 & 1 & $20.00 \%$ \\
\hline SDG 14-Life below water & 3 & 1 & $33.33 \%$ \\
\hline SDG 15-Life on land & 5 & 4 & $80.00 \%$ \\
\hline SDG 16-Peace, justice, and strong institutions & 7 & 5 & $71.43 \%$ \\
\hline SDG 17-Partnerships for the goals & 5 & 1 & $20.00 \%$ \\
\hline TOTAL & 113 & 41 & $36.28 \%$ \\
\hline
\end{tabular}

Source: own calculations.

Regarding SDG 1-End poverty in all its forms everywhere-for Bulgaria, it is estimated that in the case of 6 of 12 indicators (50\%), positive evolution will be registered, so that by 2030 the value of national indicators will reach or exceed the European average.

Extremely positive developments are expected in terms of the SDG_01_30 indicator (Severely materially deprived people), with an accelerated improvement towards the 2030 Horizon, as well as the SDG_07_60 indicator (Population unable to keep home adequately warm), which has an estimated similar evolution.

On the other hand, the lags as well as the estimated negative evolution for the indicators SDG_01_20 (People at risk of income poverty after social transfers) or SDG_01_41 (In work at-risk-of-poverty rate) present divergent developments compared to the forecasted evolution at the level of EU countries, which can have significant consequences on the level of poverty in Bulgaria, simultaneously with the deepening of some existing gaps (Table 2).

The situation of SDG 2-End hunger, achieve food security and improved nutrition, and promote sustainable agriculture-for Bulgaria is not much better than the previous objective, a degree of achievement of the indicators' targets being estimated at only $42.86 \%$.

Even if considerable improvements are estimated in the evolution of some indicators (such as SDG_02_10 or SDG_02_20), significant regressions are also registered. Thus, it is possible to mention the indicator SDG_06_40 (Nitrate in groundwater) which, based on the existing data and without additional reduction measures, is estimated to register an upward long-term trend, with a growth differential higher than the growth rate of the EU, which can have serious implications for the environment and society (Table 3 ).

Regarding the level of health and wellbeing of Bulgarian citizens, SDG 3 foresees 11 specific indicators. Of these, by 2030, Bulgaria is expected to reach convergence and performance targets of the EU average of $45.45 \%$.

Among the indicators where notable performances are recorded, we can note SDG_02_10 (Obesity rate by body mass index-BMI) which is expected to follow a downward trend, contrary to the upward trend estimated by the EU media, provided that the consumption habits of the population are not modified. Or, in the same positive light, we can mention the indicator SDG_11_50 (Exposure to air pollution by particulate matter, less than $2.5 \mu \mathrm{m}$ ) whose trend is estimated to be downward, as well as the trend estimated to be recorded at the EU average, but the decline in Bulgaria is expected to be more pronounced.

On the other hand, there are also indicators whose anticipated evolution requires increased attention, given the impact they have on the general health of the population. Thus, the indicator SDG_03_30 (Smoking prevalence) shows extremely pessimistic estimates, being estimated as a long-term growth trend, which is contrary to the anticipated evolution for the EU average, the two evolutions being perfectly antagonistic, despite the efforts sustained for reduction of tobacco consumption (Table 4). 
Table 2. SDG 1-End poverty in all its forms everywhere.

\begin{tabular}{|c|c|c|c|c|c|c|c|c|c|c|}
\hline Indicators & & 2015 & 2020 & 2025 & 2030 & 2020/2015 & 2025/2015 & 2030/2015 & Trend & Int. \\
\hline People at risk of poverty or social exclusion [SDG_01_10] (\%) & $\begin{array}{l}\mathrm{EU} \\
\mathrm{BG}\end{array}$ & $\begin{array}{l}23.80 \\
41.30\end{array}$ & $\begin{array}{l}20.15 \\
32.10\end{array}$ & $\begin{array}{l}16.44 \\
23.80\end{array}$ & $\begin{array}{l}12.72 \\
15.32\end{array}$ & $\begin{array}{l}0.85 \\
0.78\end{array}$ & $\begin{array}{l}0.69 \\
0.58\end{array}$ & $\begin{array}{l}0.53 \\
0.37\end{array}$ & DOWN & NO \\
\hline People at risk of poverty or social exclusion by degree of urbanization [SDG_01_10A] (\%) & $\begin{array}{l}\mathrm{EU} \\
\mathrm{BG}\end{array}$ & $\begin{array}{l}25.90 \\
54.80\end{array}$ & $\begin{array}{l}22.72 \\
46.70\end{array}$ & $\begin{array}{l}19.45 \\
43.20\end{array}$ & $\begin{array}{l}16.19 \\
38.78\end{array}$ & $\begin{array}{l}0.88 \\
0.85\end{array}$ & $\begin{array}{l}0.75 \\
0.79\end{array}$ & $\begin{array}{l}0.63 \\
0.71\end{array}$ & DOWN & NO \\
\hline People at risk of income poverty after social transfers [SDG_01_20] (\%) & $\begin{array}{l}\mathrm{EU} \\
\mathrm{BG}\end{array}$ & $\begin{array}{l}17.40 \\
22.00\end{array}$ & $\begin{array}{l}16.50 \\
23.80\end{array}$ & $\begin{array}{l}16.50 \\
23.73\end{array}$ & $\begin{array}{l}16.50 \\
24.44\end{array}$ & $\begin{array}{l}0.95 \\
1.08\end{array}$ & $\begin{array}{l}0.95 \\
1.08\end{array}$ & $\begin{array}{l}0.95 \\
1.11\end{array}$ & UP & NO \\
\hline People at risk of income poverty after social transfers, by citizenship [SDG_01_20A] (\%) & $\begin{array}{l}\text { EU } \\
\text { BG }\end{array}$ & $\begin{array}{l}15.60 \\
21.30\end{array}$ & $\begin{array}{l}15.35 \\
22.90\end{array}$ & $\begin{array}{l}15.35 \\
22.06\end{array}$ & $\begin{array}{l}15.35 \\
22.06\end{array}$ & $\begin{array}{l}0.98 \\
1.08\end{array}$ & $\begin{array}{l}0.98 \\
1.04 \\
\end{array}$ & $\begin{array}{l}0.98 \\
1.04 \\
\end{array}$ & SIDEWAYS & NO \\
\hline Severely materially deprived people [SDG_01_30] (\%) & $\begin{array}{l}\text { EU } \\
\text { BG }\end{array}$ & $\begin{array}{c}8.40 \\
34.20\end{array}$ & $\begin{array}{l}4.90 \\
19.40\end{array}$ & $\begin{array}{l}1.89 \\
8.02\end{array}$ & $\begin{array}{l}-1.11 \\
-4.26\end{array}$ & $\begin{array}{l}0.58 \\
0.57\end{array}$ & $\begin{array}{l}0.23 \\
0.23\end{array}$ & $\begin{array}{l}-0.13 \\
-0.12 \\
\end{array}$ & DOWN & YES \\
\hline People living in households with very low work intensity [SDG_01_40] (\%) & $\begin{array}{l}\mathrm{EU} \\
\mathrm{BG}\end{array}$ & $\begin{array}{l}10.50 \\
11.60\end{array}$ & $\begin{array}{l}7.72 \\
8.50\end{array}$ & $\begin{array}{l}4.89 \\
4.50\end{array}$ & $\begin{array}{l}2.06 \\
0.50\end{array}$ & $\begin{array}{l}0.74 \\
0.73\end{array}$ & $\begin{array}{l}0.47 \\
0.39\end{array}$ & $\begin{array}{l}0.20 \\
0.04\end{array}$ & DOWN & YES \\
\hline In work at-risk-of-poverty rate [SDG_01_41] (\%) & $\begin{array}{l}\mathrm{EU} \\
\mathrm{BG}\end{array}$ & $\begin{array}{l}9.70 \\
7.70\end{array}$ & $\begin{array}{l}9.00 \\
9.60\end{array}$ & $\begin{array}{c}9.00 \\
11.43\end{array}$ & $\begin{array}{c}9.00 \\
12.76\end{array}$ & $\begin{array}{l}0.93 \\
1.25\end{array}$ & $\begin{array}{l}0.93 \\
1.48\end{array}$ & $\begin{array}{l}0.93 \\
1.66\end{array}$ & UP & NO \\
\hline $\begin{array}{l}\text { Population living in a dwelling with a leaking roof, damp walls, floors, or foundation or } \\
\text { rot in window frames or floor by poverty status [SDG_01_60] (\%) }\end{array}$ & $\begin{array}{l}\text { EU } \\
\text { BG }\end{array}$ & $\begin{array}{l}15.30 \\
12.90\end{array}$ & $\begin{array}{l}12.72 \\
11.00\end{array}$ & $\begin{array}{l}11.00 \\
5.46 \\
\end{array}$ & $\begin{array}{l}9.27 \\
1.15 \\
\end{array}$ & $\begin{array}{l}0.83 \\
0.85 \\
\end{array}$ & $\begin{array}{l}0.72 \\
0.42 \\
\end{array}$ & $\begin{array}{l}0.61 \\
0.09 \\
\end{array}$ & DOWN & YES \\
\hline Self-reported unmet need for medical examination and care by sex [SDG_03_60] (\%) & $\begin{array}{l}\mathrm{EU} \\
\mathrm{BG} \\
\end{array}$ & $\begin{array}{l}2.80 \\
2.80 \\
\end{array}$ & $\begin{array}{c}1.70 \\
-0.41 \\
\end{array}$ & $\begin{array}{c}1.70 \\
-6.69 \\
\end{array}$ & $\begin{array}{c}1.70 \\
-12.20 \\
\end{array}$ & $\begin{array}{c}0.61 \\
-0.15 \\
\end{array}$ & $\begin{array}{c}0.61 \\
-2.39 \\
\end{array}$ & $\begin{array}{c}0.61 \\
-4.36 \\
\end{array}$ & DOWN & YES \\
\hline $\begin{array}{l}\text { Population having neither a bath, nor a shower, nor indoor flushing toilet in their } \\
\text { household by poverty status [SDG_06_10] (\%) }\end{array}$ & $\begin{array}{l}\text { EU } \\
\text { BG }\end{array}$ & $\begin{array}{c}2.20 \\
11.10\end{array}$ & $\begin{array}{l}1.57 \\
7.00\end{array}$ & $\begin{array}{l}0.95 \\
2.27\end{array}$ & $\begin{array}{c}0.33 \\
-2.46\end{array}$ & $\begin{array}{l}0.71 \\
0.63\end{array}$ & $\begin{array}{l}0.43 \\
0.20\end{array}$ & $\begin{array}{c}0.15 \\
-0.22\end{array}$ & DOWN & YES \\
\hline Overcrowding rate by poverty status [SDG_11_10] (\%) & $\begin{array}{l}\mathrm{EU} \\
\mathrm{BG}\end{array}$ & $\begin{array}{l}18.10 \\
41.40\end{array}$ & $\begin{array}{l}17.23 \\
39.50\end{array}$ & $\begin{array}{l}16.65 \\
35.60\end{array}$ & $\begin{array}{l}16.08 \\
31.76\end{array}$ & $\begin{array}{l}0.95 \\
0.95\end{array}$ & $\begin{array}{l}0.92 \\
0.86\end{array}$ & $\begin{array}{l}0.89 \\
0.77\end{array}$ & DOWN & NO \\
\hline
\end{tabular}

Source: Eurostat, own calculations. 
Table 3. SDG 2-End hunger, achieve food security and improved nutrition, and promote sustainable agriculture.

\begin{tabular}{|c|c|c|c|c|c|c|c|c|c|c|}
\hline Indicators & & 2015 & 2020 & 2025 & 2030 & $2020 / 2015$ & $2025 / 2015$ & $2030 / 2015$ & Trend & Int. \\
\hline \multirow{2}{*}{ Obesity rate by body mass index (BMI) [SDG_02_10] (index) } & $\mathrm{EU}$ & 51.60 & 52.93 & 54.50 & 56.08 & 1.03 & 1.06 & 1.09 & \multirow[b]{2}{*}{ DOWN } & \multirow[b]{2}{*}{ YES } \\
\hline & BG & 56.00 & 55.46 & 50.59 & 45.60 & 0.99 & 0.94 & 0.89 & & \\
\hline Agricultural factor income per annual work unit (AWU) [SDG_02_20] (index) & EU & 110.36 & 127.20 & 147.17 & 163.83 & 1.15 & 1.33 & 1.48 & UP & YES \\
\hline \multirow{2}{*}{$\begin{array}{l}\text { Government support for agricultural research and development [SDG_02_30] } \\
\text { (EUR million) }\end{array}$} & EU & 2605.0 & 3067.5 & 3067.3 & 3067.3 & 1.18 & 1.18 & 1.18 & \multirow[b]{2}{*}{ SIDEWAYS } & \multirow[b]{2}{*}{$\mathrm{NO}$} \\
\hline & BG & 17.29 & 25.42 & 19.29 & 19.29 & 1.47 & 1.12 & 1.12 & & \\
\hline \multirow{2}{*}{ Area under organic farming [SDG_02_40] (\%) } & EU & 6.56 & 9.24 & 11.11 & 12.61 & 1.41 & 1.69 & 1.92 & \multirow[b]{2}{*}{$\mathrm{UP}$} & \multirow{2}{*}{$\mathrm{NO}$} \\
\hline & BG & 2.37 & 2.68 & 3.53 & 4.21 & 1.13 & 1.49 & 1.78 & & \\
\hline \multirow{2}{*}{ Harmonized risk indicator for pesticides (HRI1) [SDG_02_51] (index) } & EU & 97 & 73 & 57 & 45 & 0.75 & 0.59 & 0.46 & \multirow[b]{2}{*}{ SIDEWAYS } & \multirow{2}{*}{$\mathrm{NO}$} \\
\hline & $\mathrm{BG}$ & 27 & 72 & 72 & 72 & 2.67 & 2.67 & 2.67 & & \\
\hline \multirow{2}{*}{ Ammonia emissions from agriculture [SDG_02_60] (ton) } & $\mathrm{EU}$ & $3,271,607$ & $3,154,666$ & $2,932,682$ & $2,710,698$ & 0.96 & 0.90 & 0.83 & \multirow{2}{*}{ SIDEWAYS } & \multirow{2}{*}{ YES } \\
\hline & BG & 37,320 & 37,026 & 37,026 & 37,026 & 0.99 & 0.99 & 0.99 & & \\
\hline \multirow{2}{*}{ Nitrate in groundwater [SDG_06_40] (mg per liter) } & EU & 21.33 & 22.29 & 23.31 & 24.34 & 1.04 & 1.09 & 1.14 & \multirow[b]{2}{*}{ UP } & \multirow[b]{2}{*}{$\mathrm{NO}$} \\
\hline & BG & 31.26 & 31.67 & 34.19 & 36.71 & 1.01 & 1.09 & 1.17 & & \\
\hline
\end{tabular}


In the case of SDG 4-Ensure inclusive and equitable quality education and promote lifelong learning opportunities for all-Bulgaria is expected to have an unfavorable evolution in the medium and long term, if it does not adopt corrective measures; the degree of convergence is estimated. Compared to the European average, it is indicated that for any of the 6 existing indicators the average performances of the European Union countries will not be reached.

Unfortunately, for most indicators, relatively stagnant developments are expected in the medium and long term when, on the contrary, decisive measures would have been needed to increase the quality of education and promote lifelong learning opportunities along with increasing inclusion (Table 5).

In the case of SDG 5 , as in the case of SDG 4 , the estimates made on the basis of existing data indicate that there is a fairly high probability that by 2030 the values of indicators specific to this objective will register unfavorable developments compared to the environment of other European countries.

Unfortunately, it seems that Bulgaria performs the least in terms of gender equality and empowerment for all women. We can mention the indicator SDG_05_30 (Gender employment gap) which in the case of Bulgaria has estimated an upward trend, based on almost a doubling of the gap between 2015 and 2030, contrary to the estimated trend at the EU level which is downward, a decrease of about $30 \%$ in 2030 being estimated, compared to the base period of 2015. The indicator SDG_05_40 (Inactive population due to caring responsibilities) can also be discussed, for which a strong ascending evolution is estimated, which could lead to a doubling of the value in 2030 compared to 2015, if no corrective measures are adopted (Table 6).

For SDG 6-Ensure availability and sustainable management of water and sanitation for all-the estimates made on the basis of available data indicate a relatively high degree of convergence $(71.43 \%)$ of the forecast values for national indicators and average indicators at EU level, for the year 2030.

The indicator with the most unfavorable forecasted evolution, in the case of this SDG, is the indicator SDG_06_50 (Phosphate in rivers) for which an upward trend is estimated, contrary to the downward trend registered at EU level.

On the other hand, there are also positive developments, with significant impact on the environment and the population, such as the indicator SDG_06_10 (Population having neither a bath, nor a shower, nor indoor flushing toilet in their household), for which a considerable reduction is estimated towards elimination of these situations, or the indicator SDG_06_60 (Water exploitation index), which suggests that the efficiency of the use of water resources is in continuous improvement, at a level much higher than the average value of this indicator at EU level (Table 7).

Regarding access to affordable, reliable, sustainable, and modern energy for all (SDG 7) in Bulgaria, we find that based on the estimates of dynamic indicators and trends of specific indicators, we can approximate a degree of $50 \%$ achievement of the assumed targets, respectively, for 4 of the 8 indicators.

The most positive estimates are related to the indicator SDG_07_40 (Share of renewable energy in gross final energy consumption), for which a positive trend is forecast, doubled by an encouraging dynamic, the analysis indicating a potential increase of $81 \%$ of the share of renewable energy in Bulgaria compared to an estimated 51\% increase in the EU average, proof that all political and financial efforts have a chance to bear fruit.

Bulgaria is also showing very good results in terms of the indicator SDG_07_50 (Energy import dependency), for which it is expected to register a downward trend, as opposed to the upward trend estimated at EU level (Table 8).

The potential targets for SDG 8 specific indicators-Promote sustained, inclusive, and sustainable economic growth, full and productive employment, and decent work for all-are not encouraging in Bulgaria, with estimates indicating that only 2 of the 9 indicators $(22.22 \%)$ assume that it is possible to reach a level at least equal to the EU average. 
Table 4. SDG 3-Ensure healthy lives and promote wellbeing for everyone at all ages.

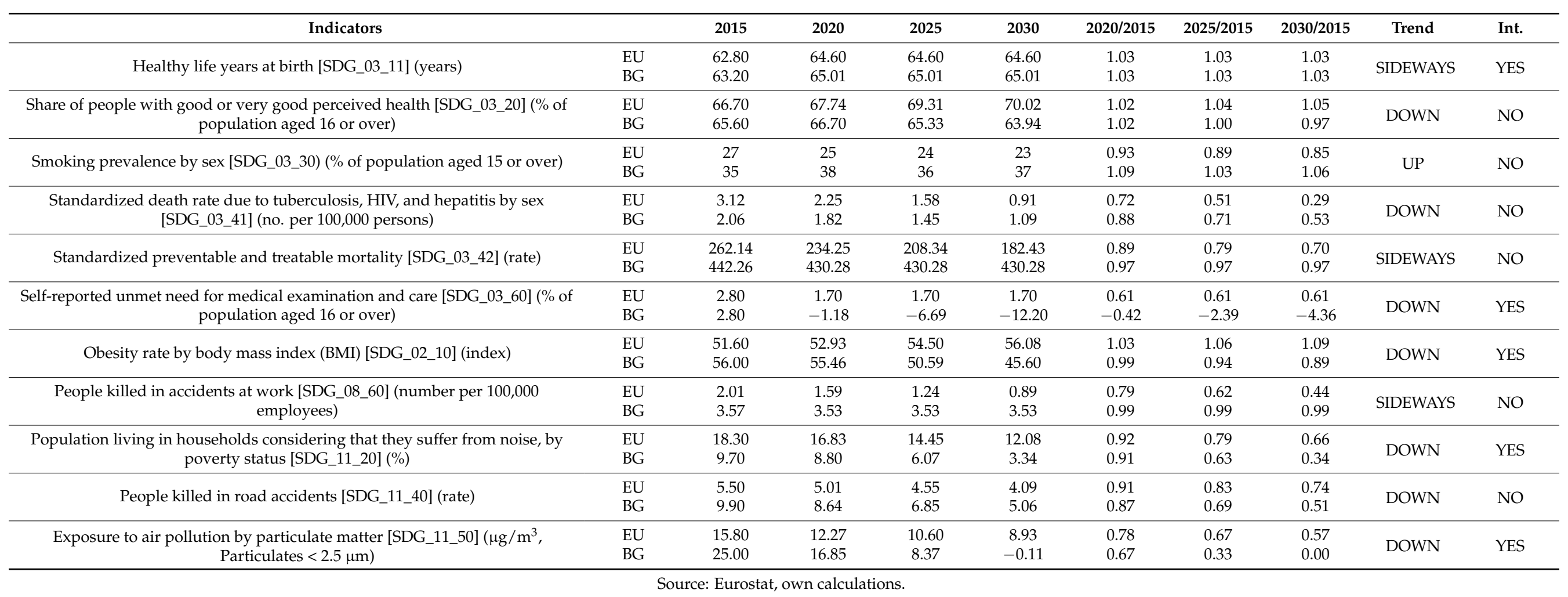


Table 5. SDG 4-Ensure inclusive and equitable quality education and promote lifelong learning opportunities for all.

\begin{tabular}{|c|c|c|c|c|c|c|c|c|c|c|}
\hline Indicators & & 2015 & 2020 & 2025 & 2030 & $2020 / 2015$ & $2025 / 2015$ & $2030 / 2015$ & Trend & Int. \\
\hline \multirow{2}{*}{ Early leavers from education and training [SDG_04_10] (\% of population aged 18 to 24) } & EU & 11.00 & 9.90 & 8.49 & 7.07 & 0.90 & 0.77 & 0.64 & \multirow{2}{*}{ SIDEWAYS } & \multirow{2}{*}{ NO } \\
\hline & BG & 13.40 & 12.80 & 12.81 & 12.81 & 0.96 & 0.96 & 0.96 & & \\
\hline \multirow{2}{*}{$\begin{array}{l}\text { Tertiary educational attainment [SDG_04_20] } \\
\text { (\% of population aged } 30 \text { to } 34)\end{array}$} & EU & 36.50 & 40.50 & 44.10 & 47.96 & 1.11 & 1.21 & 1.31 & \multirow{2}{*}{ UP } & \multirow{2}{*}{ NO } \\
\hline & BG & 31.80 & 33.00 & 36.12 & 39.23 & 1.04 & 1.14 & 1.23 & & \\
\hline \multirow{2}{*}{ Participation in early childhood education [SDG_04_31] (\%) } & EU & 91.90 & 92.92 & 93.96 & 94.99 & 1.01 & 1.02 & 1.03 & \multirow{2}{*}{ SIDEWAYS } & \multirow{2}{*}{$\mathrm{NO}$} \\
\hline & BG & 84.80 & 80.00 & 80.50 & 81.00 & 0.94 & 0.95 & 0.96 & & \\
\hline \multirow{2}{*}{$\begin{array}{l}\text { Underachievement in reading, math, or science [SDG_04_40] (\% of 15-year-old students, } \\
\text { reading) }\end{array}$} & EU & 20.00 & 21.15 & 21.08 & 21.02 & 1.06 & 1.05 & 1.05 & \multirow[b]{2}{*}{ SIDEWAYS } & \multirow[b]{2}{*}{$\mathrm{NO}$} \\
\hline & BG & 41.50 & 43.91 & 43.19 & 42.47 & 1.06 & 1.04 & 1.02 & & \\
\hline \multirow{2}{*}{$\begin{array}{l}\text { Adult participation in learning [SDG_04_60] } \\
\text { (\% of population aged } 25 \text { to } 64)\end{array}$} & EU & 10.10 & 9.20 & 9.26 & 9.26 & 0.91 & 0.92 & 0.92 & \multirow[b]{2}{*}{ SIDEWAYS } & \multirow[b]{2}{*}{$\mathrm{NO}$} \\
\hline & BG & 2.00 & 1.60 & 1.60 & 1.60 & 0.80 & 0.80 & 0.80 & & \\
\hline \multirow{2}{*}{ Share of individuals having at least basic digital skills [SDG_04_70] (\%) } & EU & 54 & 57 & 61 & 64 & 1.06 & 1.13 & 1.19 & \multirow{2}{*}{ SIDEWAYS } & \multirow{2}{*}{ NO } \\
\hline & BG & 31 & 29 & 29 & 29 & 0.94 & 0.94 & 0.94 & & \\
\hline
\end{tabular}

Source: Eurostat, own calculations.

Table 6. SDG 5-Achieve gender equality and empower all women and girls.

\begin{tabular}{|c|c|c|c|c|c|c|c|c|c|c|}
\hline Indicators & & 2015 & 2020 & 2025 & 2030 & $2020 / 2015$ & $2025 / 2015$ & $2030 / 2015$ & Trend & Int. \\
\hline \multirow{2}{*}{$\begin{array}{l}\text { Gender pay gap in unadjusted form [SDG_05_20] } \\
\text { (\% of average gross hourly earnings of men) }\end{array}$} & EU & 15.50 & 13.80 & 12.30 & 10.80 & 0.89 & 0.79 & 0.70 & \multirow[b]{2}{*}{ SIDEWAYS } & \multirow[b]{2}{*}{$\mathrm{NO}$} \\
\hline & BG & 15.50 & 14.10 & 14.10 & 14.10 & 0.91 & 0.91 & 0.91 & & \\
\hline \multirow{2}{*}{ Gender employment gap [SDG_05_30] (\%) } & EU & 11.50 & 11.10 & 9.73 & 8.16 & 0.97 & 0.85 & 0.71 & \multirow[b]{2}{*}{ UP } & \multirow{2}{*}{$\mathrm{NO}$} \\
\hline & BG & 6.60 & 8.90 & 10.40 & 11.90 & 1.35 & 1.58 & 1.80 & & \\
\hline \multirow{2}{*}{$\begin{array}{l}\text { Inactive population due to caring responsibilities [SDG_05_40] } \\
(\% \text { of inactive population aged } 20 \text { to } 64)\end{array}$} & $\mathrm{EU}$ & 19.60 & 18.70 & 19.47 & 19.47 & 0.95 & 0.99 & 0.99 & \multirow[b]{2}{*}{ UP } & \multirow{2}{*}{$\mathrm{NO}$} \\
\hline & BG & 22.20 & 30.60 & 35.72 & 40.83 & 1.38 & 1.61 & 1.84 & & \\
\hline \multirow{2}{*}{ Seats held by women in national parliaments and governments [SDG_05_50] (\%) } & EU & 28.20 & 32.70 & 36.62 & 40.55 & 1.16 & 1.30 & 1.44 & \multirow[b]{2}{*}{ SIDEWAYS } & \multirow{2}{*}{$\mathrm{NO}$} \\
\hline & BG & 19.60 & 27.10 & 27.07 & 27.07 & 1.38 & 1.38 & 1.38 & & \\
\hline \multirow{2}{*}{ Positions held by women in senior management positions [SDG_05_60] (\%) } & EU & 22.20 & 29.50 & 35.24 & 40.98 & 1.33 & 1.59 & 1.85 & \multirow[b]{2}{*}{ UP } & \multirow[b]{2}{*}{$\mathrm{NO}$} \\
\hline & BG & 19.00 & 12.90 & 15.21 & 15.21 & 0.68 & 0.80 & 0.80 & & \\
\hline \multirow{2}{*}{$\begin{array}{l}\text { Early leavers from education and training [SDG_04_10] } \\
\text { (\% of population aged } 18 \text { to } 24)\end{array}$} & EU & 11.00 & 9.90 & 8.49 & 7.07 & 0.90 & 0.77 & 0.64 & \multirow[b]{2}{*}{ DOWN } & \multirow[b]{2}{*}{$\mathrm{NO}$} \\
\hline & BG & 13.40 & 12.80 & 12.81 & 12.81 & 0.96 & 0.96 & 0.96 & & \\
\hline \multirow{2}{*}{$\begin{array}{l}\text { Tertiary educational attainment [SDG_04_20] } \\
\text { (\% of population aged } 30 \text { to } 34)\end{array}$} & EU & 36.50 & 40.50 & 44.10 & 47.96 & 1.11 & 1.21 & 1.31 & \multirow{2}{*}{ UP } & \multirow[b]{2}{*}{$\mathrm{NO}$} \\
\hline & BG & 31.80 & 33.00 & 36.12 & 39.23 & 1.04 & 1.14 & 1.23 & & \\
\hline
\end{tabular}


Table 7. SDG 6-Ensure availability and sustainable management of water and sanitation for all.

\begin{tabular}{|c|c|c|c|c|c|c|c|c|c|c|}
\hline Indicators & & 2015 & 2020 & 2025 & 2030 & $2020 / 2015$ & $2025 / 2015$ & $2030 / 2015$ & Trend & Int. \\
\hline \multirow{2}{*}{$\begin{array}{c}\text { Population having neither a bath, nor a shower, nor indoor flushing } \\
\text { toilet in their household by poverty status [SDG_06_10] }(\%)\end{array}$} & EU & 2.20 & 1.57 & 0.95 & 0.33 & 0.71 & 0.43 & 0.15 & \multirow[b]{2}{*}{ DOWN } & \multirow[b]{2}{*}{ YES } \\
\hline & BG & 11.10 & 7.00 & 2.27 & -2.46 & 0.63 & 0.20 & -0.22 & & \\
\hline \multirow{2}{*}{$\begin{array}{l}\text { Population connected to at least secondary wastewater treatment } \\
\qquad[\text { SDG_06_20] }(\%)\end{array}$} & EU & - & - & - & - & - & - & - & \multirow[b]{2}{*}{ DOWN } & \multirow[b]{2}{*}{ N/A } \\
\hline & BG & 60.63 & 70.45 & 82.28 & 94.12 & 1.16 & 1.36 & 1.55 & & \\
\hline \multirow{2}{*}{ Biochemical oxygen demand in rivers [SDG_06_30] ( $\mathrm{mg} \mathrm{O}_{2}$ per liter) } & EU & 2.09 & 1.99 & 1.85 & 1.70 & 0.95 & 0.88 & 0.81 & \multirow[b]{2}{*}{ DOWN } & \multirow[b]{2}{*}{ YES } \\
\hline & BG & 2.63 & 1.97 & 1.29 & 0.61 & 0.75 & 0.49 & 0.23 & & \\
\hline \multirow{2}{*}{ Nitrate in groundwater [SDG_06_40] (mg NO 3 per liter) } & EU & 21.33 & 22.29 & 23.31 & 24.34 & 1.04 & 1.09 & 1.14 & \multirow[b]{2}{*}{ UP } & \multirow[b]{2}{*}{$\mathrm{NO}$} \\
\hline & BG & 31.26 & 31.67 & 34.19 & 36.71 & 1.01 & 1.09 & 1.17 & & \\
\hline \multirow{2}{*}{ Phosphate in rivers [SDG_06_50] (mg $\mathrm{PO}_{4}$ per liter) } & $\mathrm{EU}$ & 0.06 & 0.05 & 0.01 & -0.02 & 0.81 & 0.20 & -0.41 & \multirow{2}{*}{ UP } & \multirow{2}{*}{$\mathrm{NO}$} \\
\hline & BG & 0.09 & 0.14 & 0.22 & 0.31 & 1.48 & 2.37 & 3.25 & & \\
\hline \multirow{2}{*}{ Water exploitation index, plus (WEI+) [SDG_06_60] (\%) } & EU & 8.40 & 7.69 & 7.69 & 7.69 & 0.92 & 0.92 & 0.92 & \multirow{2}{*}{ SIDEWAYS } & \multirow{2}{*}{ YES } \\
\hline & BG & 1.35 & 1.60 & 1.60 & 1.60 & 1.18 & 1.18 & 1.18 & & \\
\hline \multirow{2}{*}{$\begin{array}{l}\text { Bathing sites with excellent water quality by locality [SDG_14_40] (\%, } \\
\text { coastal water excellent) }\end{array}$} & EU & 86.98 & 89.25 & 93.69 & 98.14 & 1.03 & 1.08 & 1.13 & \multirow{2}{*}{ SIDEWAYS } & \multirow{2}{*}{$\mathrm{NO}$} \\
\hline & $\mathrm{BG}$ & 70.00 & 61.04 & 61.04 & 61.04 & 0.87 & 0.87 & 0.87 & & \\
\hline
\end{tabular}


The most unfavorable developments are estimated for the indicators SDG_08_11 (Investment share of GDP) and SDG_01_41 (In work at-risk-of-poverty rate), in both cases the estimated trend at national level being divergent from the estimated trend at EU level, with the effect of widening the disparities between Bulgaria and the rest of the Member States.

Regarding other indicators related to this SDG, the estimated trends in Bulgaria are convergent with the projected trends in the EU, but the rates suggested by the dynamic indicators indicate a speed difference, which will generate, in the long run, a sharpening of existing disparities (Table 9).

Estimating the evolution of specific indicators, SDG 9-Build resilient infrastructure, promote inclusive and sustainable industrialization, and foster innovation-suggests a rather unfavorable situation for Bulgaria; only for 1 (respectively SDG_09_60) of the 7 indicators is there the possibility to achieve a performance level, respectively, to reach at least the European average, which represents a degree of fulfillment of only $14.29 \%$ of this SDG.

Except for the indicator SDG_09_50 (Share of buses and trains in total passenger transport), for which a trend is estimated to be divergent from the anticipated evolution at European level, for the rest of the indicators there is an estimated trend converging with the EU trend, but the basic difference (2015) between Bulgaria and the EU average is far too high to be recovered by 2030, especially since Europe is not standing still.

Thus, we appreciate that there is potential in terms of achieving remarkable performances in terms of SDG 9, especially since Bulgaria is in a favorable position in terms of results obtained so far (Table 10).

Regarding the reduction of inequalities within and among countries (SDG 10), the results of the analysis suggest a rather unfavorable situation for Bulgaria; for only 2 of the 10 indicators $(20 \%)$ is the probability to reach the average value at EU level estimated.

In general, the causes underlying this low level of performance are related to the significant differences existing in the base year of the analysis (2015) between the reality in Bulgaria and the much more advanced level recorded by the other Member States, which generated consistent disparities. Even if the percentage of achievement of the assumed targets is low, the fact that the estimated trends are convergent proves that Bulgaria is firmly on the European path, and keeping at least the same pace of development will give it a much better position in the future (Table 11).

A better situation in Bulgaria is observed in connection with the implementation of SDG 11-Make cities and human settlements inclusive, safe, resilient, and sustainable-for which a specific target of $60 \%$ is forecast by 2030 .

For three of the four indicators for which an unfavorable evolution is estimated, a similar situation is observed, namely the estimation of a national trend converging with the European trend, but due to the large differences in 2015 regarding the values between the indicators calculated for Bulgaria and the EU average, it only remains a matter of time to recover the existing differences.

High performances can be noticed for Bulgaria in the evolution forecasts until 2030 for the indicators SDG_11_20 (Population living in households considering that they suffer from noise, by poverty status), SDG_11_50 (Exposure to air pollution by particulate matter), and SDG_16_20 (Population reporting occurrence of crime, violence, or vandalism in their area by poverty status) (Table 12).

Bulgaria's performance in implementing SDG 12-Ensure suitable consumption and production patterns - is not able to provide a good perspective, given that only one of the six representative indicators (respectively, SDG_12_20) is anticipated to reach the possibility of achieving a performance level similar to the EU average in 2030, which represents a degree of performance of only $16.67 \%$. 
Table 8. SDG 7-Ensure access to affordable, reliable, sustainable, and modern energy for all.

\begin{tabular}{|c|c|c|c|c|c|c|c|c|c|c|}
\hline Indicators & & 2015 & 2020 & 2025 & 2030 & $2020 / 2015$ & $2025 / 2015$ & $2030 / 2015$ & Trend & Int. \\
\hline \multirow{2}{*}{ Primary energy consumption [SDG_07_10] (index) } & EU & 90.40 & 88.72 & 85.19 & 81.66 & 0.98 & 0.94 & 0.90 & \multirow[b]{2}{*}{ SIDEWAYS } & \multirow{2}{*}{$\mathrm{NO}$} \\
\hline & BG & 93.50 & 93.51 & 93.51 & 93.51 & 1.00 & 1.00 & 1.00 & & \\
\hline \multirow{2}{*}{ Final energy consumption [SDG_07_11] (index) } & EU & 92.10 & 94.60 & 94.60 & 94.60 & 1.03 & 1.03 & 1.03 & \multirow{2}{*}{ SIDEWAYS } & \multirow{2}{*}{$\mathrm{NC}$} \\
\hline & BG & 93.60 & 97.00 & 97.00 & 97.00 & 1.04 & 1.04 & 1.04 & & \\
\hline \multirow{2}{*}{$\begin{array}{l}\text { Final energy consumption in households per capita [SDG_07_20] } \\
\qquad(\mathrm{KGOE})\end{array}$} & EU & 552 & 550 & 529 & 507 & 1.00 & 0.96 & 0.92 & \multirow{2}{*}{ SIDEWAYS } & \multirow{2}{*}{ YES } \\
\hline & BG & 306 & 310 & 310 & 310 & 1.01 & 1.01 & 1.01 & & \\
\hline Energy productivity [SDG_07_30] (EUR per KGOE) & EU & 7.74 & 8.37 & 9.04 & 9.70 & 1.08 & 1.17 & 1.25 & $\mathrm{UP}$ & NC \\
\hline \multirow{2}{*}{$\begin{array}{l}\text { Share of renewable energy in gross final energy consumption } \\
\text { [SDG_07_40] (\%) }\end{array}$} & $\mathrm{EU}$ & 17.84 & 20.39 & 23.66 & 26.94 & 1.14 & 1.33 & 1.51 & \multirow[b]{2}{*}{ UP } & \multirow[b]{2}{*}{ YE } \\
\hline & BG & 18.26 & 22.60 & 27.80 & 32.99 & 1.24 & 1.52 & 1.81 & & \\
\hline \multirow{2}{*}{$\begin{array}{c}\text { Energy import dependency by products [SDG_07_50] (\% of imports in } \\
\text { total energy consumption) }\end{array}$} & $\mathrm{EU}$ & 56.01 & 61.94 & 69.30 & 76.67 & 1.11 & 1.24 & 1.37 & \multirow[b]{2}{*}{ DOWN } & \multirow[b]{2}{*}{ YES } \\
\hline & BG & 36.45 & 37.01 & 31.54 & 26.07 & 1.02 & 0.87 & 0.72 & & \\
\hline \multirow{2}{*}{$\begin{array}{l}\text { Population unable to keep home adequately warm by poverty status } \\
\text { [SDG_07_60] (\%) }\end{array}$} & EU & 9.60 & 6.24 & 2.90 & -0.43 & 0.65 & 0.30 & -0.04 & \multirow[b]{2}{*}{ DOWN } & \multirow[b]{2}{*}{ YES } \\
\hline & BG & 39.20 & 25.18 & 8.71 & -7.77 & 0.64 & 0.22 & -0.20 & & \\
\hline $\begin{array}{l}\text { Greenhouse gas emissions intensity of energy consumption } \\
\text { [SDG_13_20] (index) }\end{array}$ & $\mathrm{EU}$ & 88.80 & 81.73 & 76.35 & 70.98 & 0.92 & 0.86 & 0.80 & DOWN & $\mathrm{NO}$ \\
\hline
\end{tabular}


Table 9. SDG 8-Promote sustained, inclusive, and sustainable economic growth, full and productive employment, and decent work for all.

\begin{tabular}{|c|c|c|c|c|c|c|c|c|c|c|}
\hline Indicators & & 2015 & 2020 & 2025 & 2030 & $2020 / 2015$ & $2025 / 2015$ & $2030 / 2015$ & Trend & Int. \\
\hline \multirow{2}{*}{ Real GDP per capita [SDG_08_10] (EUR per capita) } & EU & 25,950 & 26,370 & 26,370 & 26,370 & 1.02 & 1.02 & 1.02 & \multirow[b]{2}{*}{ UP } & \multirow[b]{2}{*}{$\mathrm{NO}$} \\
\hline & BG & 5790 & 6600 & 7285 & 7969 & 1.14 & 1.26 & 1.38 & & \\
\hline \multirow{2}{*}{ Investment share of GDP [SDG_08_11] (\% of GDP) } & EU & 20.57 & 22.33 & 25.25 & 27.82 & 1.09 & 1.23 & 1.35 & \multirow{2}{*}{ DOWN } & \multirow{2}{*}{$\mathrm{NO}$} \\
\hline & BG & 21.01 & 15.59 & 10.70 & 5.81 & 0.74 & 0.51 & 0.28 & & \\
\hline \multirow{2}{*}{$\begin{array}{l}\text { Young people neither in employment nor in education and training } \\
\text { [SDG_08_20] (\% of population aged } 15 \text { to } 29)\end{array}$} & EU & 15.2 & 13.70 & 13.70 & 13.70 & 0.90 & 0.90 & 0.90 & \multirow[b]{2}{*}{ DOWN } & \multirow[b]{2}{*}{$\mathrm{NO}$} \\
\hline & BG & 22.2 & 18.10 & 18.10 & 18.10 & 0.82 & 0.82 & 0.82 & & \\
\hline \multirow{2}{*}{ Employment rate [SDG_08_30] (\% of population aged 20 to 64) } & EU & 69.1 & 72.50 & 73.04 & 73.44 & 1.05 & 1.06 & 1.06 & \multirow{2}{*}{ SIDEWAYS } & \multirow{2}{*}{ YES } \\
\hline & BG & 67.1 & 73.40 & 73.40 & 73.40 & 1.09 & 1.09 & 1.09 & & \\
\hline \multirow{2}{*}{ Long-term unemployment rate [SDG_08_40] ( $\%$ of active population) } & EU & 4.8 & 2.40 & 1.40 & 0.40 & 0.50 & 0.29 & 0.08 & \multirow[b]{2}{*}{ DOWN } & \multirow[b]{2}{*}{$\mathrm{NO}$} \\
\hline & BG & 5.6 & 2.30 & 1.80 & 1.30 & 0.41 & 0.32 & 0.23 & & \\
\hline \multirow{2}{*}{$\begin{array}{l}\text { People killed in accidents at work [SDG_08_60] (number per } \\
100,000 \text { employees) }\end{array}$} & EU & 2.01 & 1.59 & 1.24 & 0.89 & 0.79 & 0.62 & 0.44 & \multirow[b]{2}{*}{ SIDEWAYS } & \multirow[b]{2}{*}{$\mathrm{NO}$} \\
\hline & BG & 3.57 & 3.53 & 3.53 & 3.53 & 0.99 & 0.99 & 0.99 & & \\
\hline \multirow{2}{*}{ In work at-risk-of-poverty rate [SDG_01_41] (\%) } & EU & 9.70 & 9.00 & 9.00 & 9.00 & 0.93 & 0.93 & 0.93 & \multirow{2}{*}{$\mathrm{UP}$} & \multirow[b]{2}{*}{$\mathrm{NO}$} \\
\hline & BG & 7.70 & 9.60 & 11.43 & 12.76 & 1.25 & 1.48 & 1.66 & & \\
\hline $\begin{array}{c}\text { Inactive population due to caring responsibilities [SDG_05_40] (\% of } \\
\text { inactive population aged } 20 \text { to } 64)\end{array}$ & EU & 19.60 & 18.70 & 19.47 & 19.47 & 0.95 & 0.99 & 0.99 & $\mathrm{UP}$ & $\mathrm{NO}$ \\
\hline \multirow{2}{*}{$\begin{array}{l}\text { Resource productivity and domestic material consumption (DMC) } \\
\text { [SDG_12_20] (index) }\end{array}$} & EU & 130.838 & 135.17 & 137.83 & 139.16 & 1.03 & 1.05 & 1.06 & \multirow[b]{2}{*}{ UP } & \multirow[b]{2}{*}{ YES } \\
\hline & BG & 111.498 & 136.21 & 142.97 & 151.39 & 1.22 & 1.28 & 1.36 & & \\
\hline
\end{tabular}


Table 10. SDG 9-Build resilient infrastructure, promote inclusive and sustainable industrialization, and foster innovation.

\begin{tabular}{|c|c|c|c|c|c|c|c|c|c|c|}
\hline Indicators & & 2015 & 2020 & 2025 & 2030 & $2020 / 2015$ & $2025 / 2015$ & $2030 / 2015$ & Trend & Int. \\
\hline \multirow{2}{*}{ Gross domestic expenditure on R\&D by sector [SDG_09_10] (\% of GDP) } & EU & 2.13 & 2.23 & 2.37 & 2.51 & 1.05 & 1.11 & 1.18 & \multirow{2}{*}{ UP } & \multirow{2}{*}{$\mathrm{NO}$} \\
\hline & BG & 0.95 & 0.87 & 1.05 & 1.22 & 0.92 & 1.10 & 1.28 & & \\
\hline R\&D personnel [SDG_09_30] (\% of active population) & EU & 1.20 & 1.45 & 1.69 & 1.92 & 1.21 & 1.40 & 1.60 & UP & $\mathrm{NO}$ \\
\hline \multirow{2}{*}{$\begin{array}{l}\text { Patent applications to the European Patent Office [SDG_09_40) } \\
\text { (number per million inhabitants) }\end{array}$} & EU & 140.96 & 147.22 & 154.14 & 160.42 & 1.04 & 1.09 & 1.14 & \multirow[b]{2}{*}{ UP } & \multirow[b]{2}{*}{$\mathrm{NO}$} \\
\hline & BG & 4.60 & 7.48 & 7.48 & 9.17 & 1.63 & 1.63 & 1.99 & & \\
\hline \multirow{2}{*}{$\begin{array}{l}\text { Share of buses and trains in total passenger transport [SDG_09_50] (\% of total inland } \\
\text { passenger-km, Trains, motor coaches, buses, and trolley buses_-sum of available data) }\end{array}$} & $\mathrm{EU}$ & 17.60 & 17.42 & 17.42 & 17.42 & 0.99 & 0.99 & 0.99 & \multirow{2}{*}{ DOWN } & \multirow{2}{*}{$\mathrm{NO}$} \\
\hline & BG & 16.90 & 14.39 & 9.85 & 5.31 & 0.85 & 0.58 & 0.31 & & \\
\hline \multirow{2}{*}{$\begin{array}{l}\text { Share of rail and inland waterways activity in total freight transport [SDG_09_60] (\% of } \\
\text { total inland freight ton-km, Railways, inland waterways—sum of available data) }\end{array}$} & EU & 25.80 & 23.78 & 23.78 & 23.78 & 0.92 & 0.92 & 0.92 & \multirow[b]{2}{*}{ UP } & \multirow[b]{2}{*}{ YES } \\
\hline & BG & 45.30 & 49.52 & 62.54 & 75.56 & 1.09 & 1.38 & 1.67 & & \\
\hline \multirow{2}{*}{ Average $\mathrm{CO}_{2}$ emissions per km from new passenger cars [SDG_12_30] $\left(\mathrm{g} \mathrm{CO}_{2}\right.$ per km) } & EU & 119.10 & 124.29 & 134.76 & 145.23 & 1.04 & 1.13 & 1.22 & \multirow{2}{*}{ UP } & \multirow[b]{2}{*}{$\mathrm{NO}$} \\
\hline & BG & 130.30 & 144.57 & 181.24 & 217.92 & 1.11 & 1.39 & 1.67 & & \\
\hline \multirow{2}{*}{ High-speed internet coverage, by type of area [SDG_17_60] (\% of households) } & EU & 21.90 & 59.30 & 99.09 & 100.00 & 2.71 & 4.52 & 4.57 & \multirow{2}{*}{ UP } & \multirow[b]{2}{*}{$\mathrm{NO}$} \\
\hline & BG & 32.20 & 42.90 & 57.19 & 71.47 & 1.33 & 1.78 & 2.22 & & \\
\hline
\end{tabular}


Table 11. SDG 10-Reduce inequality within and among countries.

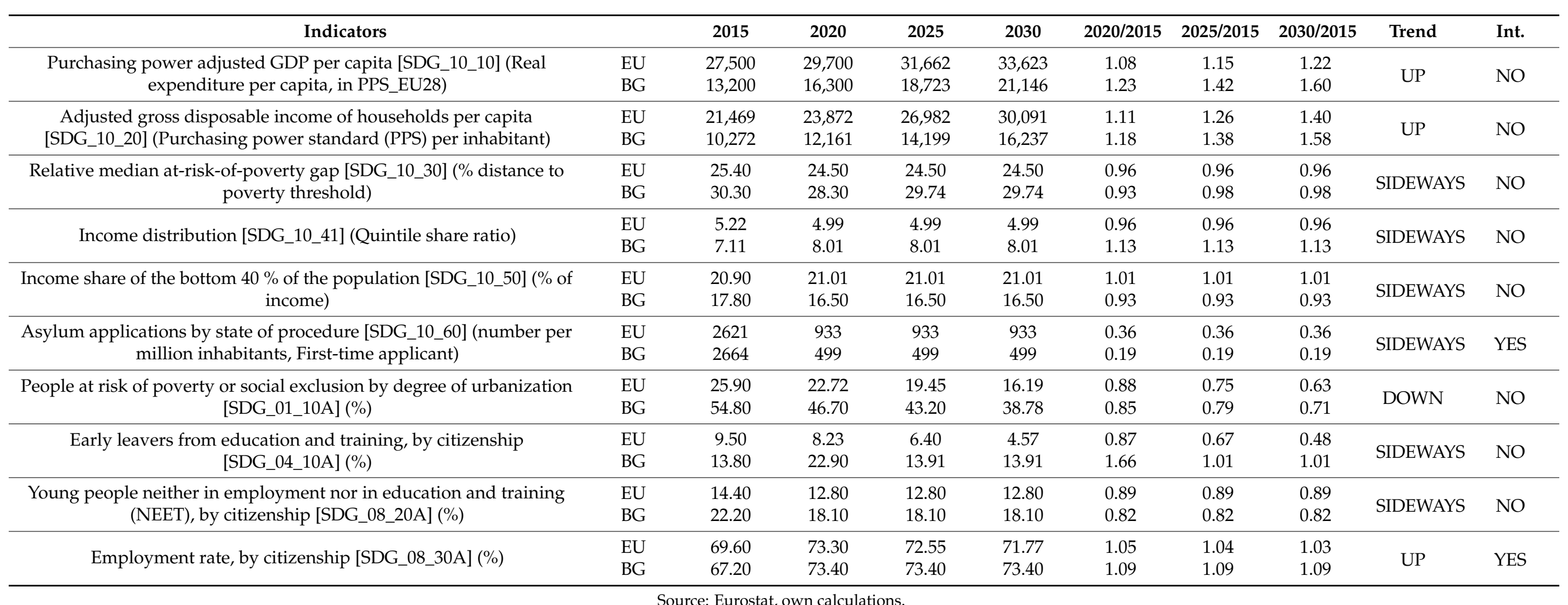


Table 12. SDG 11-Make cities and human settlements inclusive, safe, resilient, and sustainable.

\begin{tabular}{|c|c|c|c|c|c|c|c|c|c|c|}
\hline Indicators & & 2015 & 2020 & 2025 & 2030 & $2020 / 2015$ & $2025 / 2015$ & $2030 / 2015$ & Trend & Int. \\
\hline \multirow{2}{*}{ Overcrowding rate by poverty status [SDG_11_10] (\% of population) } & EU & 18.10 & 17.23 & 16.65 & 16.08 & 0.95 & 0.92 & 0.89 & \multirow[b]{2}{*}{ DOWN } & \multirow[b]{2}{*}{$\mathrm{NO}$} \\
\hline & BG & 41.40 & 39.50 & 35.60 & 31.76 & 0.95 & 0.86 & 0.77 & & \\
\hline $\begin{array}{l}\text { Population living in households considering that they suffer from noise, by poverty status } \\
\qquad[\text { SDG_11_20] (\%) }\end{array}$ & EU & 18.30 & 16.83 & 14.45 & 12.08 & 0.92 & 0.79 & 0.66 & DOWN & YES \\
\hline \multirow{2}{*}{ Settlement area per capita [SDG_11_31] (sqm per capita) } & EU & 680.60 & 724.77 & 769.33 & 816.93 & 1.06 & 1.13 & 1.20 & \multirow[b]{2}{*}{ UP } & \multirow[b]{2}{*}{ YES } \\
\hline & BG & 613.50 & 754.11 & 962.93 & 1148.95 & 1.23 & 1.57 & 1.87 & & \\
\hline \multirow{2}{*}{ People killed in road accidents [SDG_11_40] (rate) } & EU & 5.50 & 5.01 & 4.55 & 4.09 & 0.91 & 0.83 & 0.74 & \multirow[b]{2}{*}{ DOWN } & \multirow{2}{*}{$\mathrm{NO}$} \\
\hline & BG & 9.90 & 8.64 & 6.85 & 5.06 & 0.87 & 0.69 & 0.51 & & \\
\hline \multirow{2}{*}{$\begin{array}{l}\text { Exposure to air pollution by particulate matter [SDG_11_50] } \\
\qquad\left(\mu \mathrm{g} / \mathrm{m}^{3}, \text { Particulates }<2.5 \mu \mathrm{m}\right)\end{array}$} & EU & 15.80 & 12.27 & 10.60 & 8.93 & 0.78 & 0.67 & 0.57 & \multirow[b]{2}{*}{ DOWN } & \multirow[b]{2}{*}{ YES } \\
\hline & BG & 25.00 & 16.85 & 8.37 & -0.11 & 0.67 & 0.33 & 0.00 & & \\
\hline \multirow{2}{*}{ Recycling rate of municipal waste [SDG_11_60] (\% of total waste generated) } & EU & 44.90 & 48.74 & 53.95 & 59.16 & 1.09 & 1.20 & 1.32 & \multirow{2}{*}{ UP } & \multirow{2}{*}{$\mathrm{NO}$} \\
\hline & BG & 29.40 & 35.46 & 41.74 & 48.01 & 1.21 & 1.42 & 1.63 & & \\
\hline \multirow{2}{*}{$\begin{array}{l}\text { Population living in a dwelling with a leaking roof, damp walls, floors, or foundation or } \\
\text { rot in window frames or floor by poverty status [SDG_01_60] (\%) }\end{array}$} & EU & 15.30 & 12.72 & 11.00 & 9.27 & 0.83 & 0.72 & 0.61 & \multirow[b]{2}{*}{ DOWN } & \multirow[b]{2}{*}{ YES } \\
\hline & BG & 12.90 & 11.00 & 5.46 & 1.15 & 0.85 & 0.42 & 0.09 & & \\
\hline \multirow{2}{*}{ Population connected to at least secondary wastewater treatment [SDG_06_20] (\%) } & EU & - & - & - & - & - & - & - & \multirow{2}{*}{$\mathrm{UP}$} & \multirow{2}{*}{$\mathrm{N} / \mathrm{f}$} \\
\hline & BG & 60.63 & 70.45 & 82.28 & 94.12 & 1.16 & 1.36 & 1.55 & & \\
\hline $\begin{array}{l}\text { Share of buses and trains in total passenger transport [SDG_09_50] (\% of total inland } \\
\text { passenger-km, Trains, motor coaches, buses, and trolley buses_-sum of available data) }\end{array}$ & EU & 17.60 & 17.42 & 17.42 & 17.42 & 0.99 & 0.99 & 0.99 & DOWN & $\mathrm{NO}$ \\
\hline \multirow{2}{*}{$\begin{array}{l}\text { Population reporting occurrence of crime, violence, or vandalism in their area by poverty } \\
\text { status [SDG_16_20] (\% of population) }\end{array}$} & EU & 13.20 & 10.95 & 9.18 & 7.41 & 0.83 & 0.70 & 0.56 & \multirow[b]{2}{*}{ DOWN } & \multirow[b]{2}{*}{ YES } \\
\hline & BG & 26.30 & 19.10 & 9.66 & 0.13 & 0.73 & 0.37 & 0.00 & & \\
\hline
\end{tabular}


An extremely unfavorable evolution is anticipated regarding the indicator SDG_12_50 (Generation of waste excluding major mineral wastes). Even if the trend estimated for Bulgaria until 2030 coincides, as a direction, with the European trend, the difference in the dynamics of evolution is the one that raises signs of concern; for Bulgaria, an increase of $53 \%$ is anticipated compared to the base level in 2015, and for the EU average an increase of only $6 \%$ is estimated for the similar period (Table 13).

In terms of the implementation of SDG 13-Take urgent action to combat climate change and its impacts-Bulgaria does not perform much better than in the case of the other objectives, a degree of performance of only $20 \%$ being estimated, respectively; only for 1 of the 5 assumed indicators is there the possibility to reach the average level of the EU in 2030 .

In general, the argument for not achieving the desired performance levels is related to the large differences between the values of indicators in Bulgaria and the EU average in 2015. As with other indicators previously analyzed, the analysis proves the positive path that Bulgaria is following, but the speed of adjustment of existing disparities is not the right one. It is obvious that progress has been made and the continuation of this positive path is expected, but certainly additional efforts are needed to increase the dynamics of adaptation to European realities (Table 14).

For the conservation and sustainable use of the oceans, seas, and marine resources for sustainable development (SDG 14) in Bulgaria there were data available for analysis for only three indicators, and the analysis of the results suggests that for only one indicator (SDG_14_60) is the possibility estimated of reaching a significantly higher level of performance in the year 2030 than in the base period.

Even if for the remaining 2 indicators included in the analysis (SDG_14_10 and SDG_14_40) the results obtained suggest a lack of performance, we must specify that by the nature of the indicators and how they were defined, the comparison of results obtained in Bulgaria and EU average is not in favor of a sufficiently relevant analysis. In this case, the degree of performance was estimated based on the dynamics of the indicators and the development potential in the future (Table 15).

Regarding the protection of life on land (SDG 15), the situation of reaching the established targets is much better than in the case of most previous SDGs; respectively, it is estimated to achieve a significant level of performance for 4 of the 5 indicators associated with this objective, which represents a degree of implementation of $80 \%$.

There is a very good dynamic of the indicator SDG_15_10 (Share of forest area) for which an increase of the dynamics index is forecast at $37 \%$ compared to the base period (2015), compared to the similar evolution at Member State level, for which it is estimated as an increase of only $4 \%$ (Table 16).

For SDG 16-Promote peaceful and inclusive societies for sustainable development, provide access to justice for all, and build effective, accountable, and inclusive institutions at all levels - the trend and dynamics for 7 indicators were analyzed, the analysis suggesting the fact that for 5 of them it is possible to achieve appropriate levels of performance, which indicates a satisfactory degree of achievement of the established targets of $71.43 \%$, compared to the average performance at European level.

Moreover, the indicator SDG_16_60 (Population with confidence in EU institutions), due to its relevance, was analyzed at the level of the two component European institutions, respectively, the European Parliament and the European Commission, in order to observe if there are differences of perception. The obtained results indicate the existence of a divergent trend in Bulgaria compared to the European trend, a situation that suggests the exacerbation of the lack of trust in the European institutions. In fact, this mistrust appears more and more often in the analysis carried out at European level and marks its presence more widely in the countries of the Balkans or Central Europe (Table 17). 
Table 13. SDG 12-Ensure suitable consumption and production patterns.

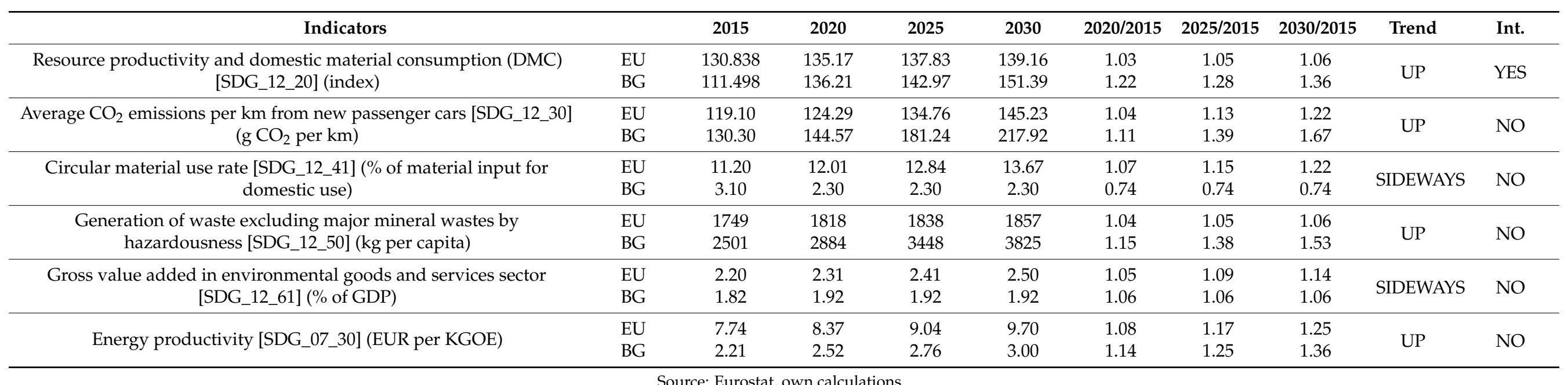

Table 14. SDG 13-Take urgent action to combat climate change and its impacts.

\begin{tabular}{|c|c|c|c|c|c|c|c|c|c|c|}
\hline Indicators & & 2015 & 2020 & 2025 & 2030 & $2020 / 2015$ & $2025 / 2015$ & $2030 / 2015$ & Trend & Int. \\
\hline \multirow{2}{*}{$\begin{array}{c}\text { Greenhouse gas emissions [SDG_13_10] (Greenhouse gas emissions } \\
\text { (in } \mathrm{CO}_{2} \text { equivalent), base year 1990) }\end{array}$} & $\mathrm{EU}$ & 77.10 & 72.63 & 65.25 & 57.88 & 0.94 & 0.85 & 0.75 & \multirow{2}{*}{ SIDEWAYS } & \multirow{2}{*}{$\mathrm{NC}$} \\
\hline & BG & 64.40 & 61.48 & 61.48 & 61.48 & 0.95 & 0.95 & 0.95 & & \\
\hline \multirow{2}{*}{$\begin{array}{l}\text { Greenhouse gas emissions intensity of energy consumption } \\
\text { [SDG_13_20] (Index, 2000 = 100) }\end{array}$} & $\mathrm{EU}$ & 88.80 & 81.73 & 76.35 & 70.98 & 0.92 & 0.86 & 0.80 & \multirow[b]{2}{*}{ DOWN } & \multirow{2}{*}{$\mathrm{NC}$} \\
\hline & BG & 111.60 & 97.10 & 97.10 & 97.10 & 0.87 & 0.87 & 0.87 & & \\
\hline \multirow{2}{*}{$\begin{array}{l}\text { Population covered by the Covenant of Mayors for Climate \& Energy } \\
\text { signatories [SDG_13_60] (\%) }\end{array}$} & $\mathrm{EU}$ & 41.20 & 44.06 & 45.63 & 46.69 & 1.07 & 1.11 & 1.13 & \multirow{2}{*}{ UP } & \multirow{2}{*}{$\mathrm{NC}$} \\
\hline & BG & 36.00 & 36.60 & 37.11 & 37.61 & 1.02 & 1.03 & 1.04 & & \\
\hline $\begin{array}{l}\text { Share of renewable energy in gross final energy consumption } \\
\text { [SDG_07_40] }(\%)\end{array}$ & $\mathrm{EU}$ & 17.84 & 20.39 & 23.66 & 26.94 & 1.14 & 1.33 & 1.51 & UP & YES \\
\hline \multirow{2}{*}{$\begin{array}{l}\text { Average } \mathrm{CO}_{2} \text { emissions per } \mathrm{km} \text { from new passenger cars [SDG_12_30] } \\
\qquad\left(\mathrm{g} \mathrm{CO}_{2} \text { per } \mathrm{km}\right)\end{array}$} & $\mathrm{EU}$ & 119.10 & 124.29 & 134.76 & 145.23 & 1.04 & 1.13 & 1.22 & \multirow{2}{*}{ UP } & \multirow[b]{2}{*}{$\mathrm{NC}$} \\
\hline & BG & 130.30 & 144.57 & 181.24 & 217.92 & 1.11 & 1.39 & 1.67 & & \\
\hline
\end{tabular}


Table 15. SDG 14-Conserve and sustainably use the oceans, seas, and marine resources for sustainable development.

\begin{tabular}{|c|c|c|c|c|c|c|c|c|c|c|}
\hline Indicators & & 2015 & 2020 & 2025 & 2030 & $2020 / 2015$ & $2025 / 2015$ & $2030 / 2015$ & Trend & Int. \\
\hline \multirow{2}{*}{$\begin{array}{l}\text { Surface of marine sites designated under NATURA } 2000 \text { [SDG_14_10] } \\
\qquad\left(\mathrm{km}^{2}\right)\end{array}$} & $\mathrm{EU}$ & 286,145 & 503,196 & 727,909 & 952,621 & 1.76 & 2.54 & 3.33 & \multirow[b]{2}{*}{ SIDEWAYS } & \multirow[b]{2}{*}{$\mathrm{NC}$} \\
\hline & BG & 2827 & 2827 & 2827 & 2827 & 1.00 & 1.00 & 1.00 & & \\
\hline \multirow{2}{*}{$\begin{array}{l}\text { Bathing sites with excellent water quality by locality [SDG_14_40] } \\
\qquad(\% \text {, coastal water excellent) }\end{array}$} & $\mathrm{EU}$ & 86.98 & 89.25 & 93.69 & 98.14 & 1.03 & 1.08 & 1.13 & \multirow{2}{*}{ SIDEWAYS } & \multirow{2}{*}{$\mathrm{NO}$} \\
\hline & BG & 70.00 & 61.04 & 61.04 & 61.04 & 0.87 & 0.87 & 0.87 & & \\
\hline \multirow{2}{*}{ Marine waters affected by eutrophication [SDG_14_60] $\left(\mathrm{km}^{2}\right)$} & $\mathrm{EU}$ & 29,031 & 18,094 & 18,094 & 18,094 & 0.62 & 0.62 & 0.62 & \multirow{2}{*}{ SIDEWAYS } & \multirow{2}{*}{ YES } \\
\hline & BG & 7 & 4 & 4 & 4 & 0.57 & 0.57 & 0.57 & & \\
\hline
\end{tabular}

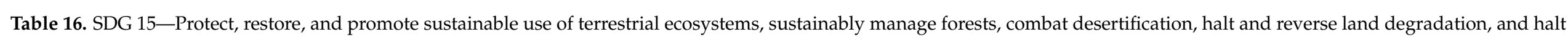
biodiversity loss.

\begin{tabular}{|c|c|c|c|c|c|c|c|c|c|c|}
\hline Indicators & & 2015 & 2020 & 2025 & 2030 & $2020 / 2015$ & $2025 / 2015$ & $2030 / 2015$ & Trend & Int. \\
\hline \multirow{2}{*}{ Share of forest area [SDG_15_10] (\% of land area) } & EU & 41.90 & 42.71 & 43.20 & 43.70 & 1.02 & 1.03 & 1.04 & \multirow{2}{*}{ UP } & \multirow{2}{*}{ YES } \\
\hline & BG & 44.70 & 50.05 & 55.74 & 61.42 & 1.12 & 1.25 & 1.37 & & \\
\hline \multirow{2}{*}{$\begin{array}{l}\text { Surface of terrestrial sites designated under NATURA } 2000 \\
\text { [SDG_15_20] (\%) }\end{array}$} & EU & 18 & 18 & 18 & 18 & 1.00 & 1.00 & 1.00 & \multirow{2}{*}{$\mathrm{UP}$} & \multirow[b]{2}{*}{ YES } \\
\hline & BG & 34 & 35 & 36 & 36 & 1.03 & 1.05 & 1.07 & & \\
\hline \multirow{2}{*}{ Soil sealing index [SDG_15_41] (index) } & EU & 104.50 & 110.58 & 117.26 & 123.92 & 1.06 & 1.12 & 1.19 & \multirow[b]{2}{*}{ UP } & \multirow[b]{2}{*}{ YES } \\
\hline & BG & 104.50 & 108.54 & 112.77 & 116.99 & 1.04 & 1.08 & 1.12 & & \\
\hline Biochemical oxygen demand in rivers [SDG_06_30] ( $\mathrm{mg} \mathrm{O}_{2}$ per liter) & EU & 2.09 & 1.99 & 1.85 & 1.70 & 0.95 & 0.88 & 0.81 & DOWN & YES \\
\hline \multirow{2}{*}{ Phosphate in rivers [SDG_06_50] ( $\mathrm{mg} \mathrm{PO}_{4}$ per liter) } & EU & 0.06 & 0.05 & 0.01 & -0.02 & 0.81 & 0.20 & -0.41 & \multirow{2}{*}{ UP } & \multirow{2}{*}{$\mathrm{NO}$} \\
\hline & BG & 0.09 & 0.14 & 0.22 & 0.31 & 1.48 & 2.37 & 3.25 & & \\
\hline
\end{tabular}

Source: Eurostat, own calculations. 
Regarding the specific indicators associated with the implementation of SDG 17Strengthen the means of implementation and revitalize the global partnership for sustainable development-following the analysis it was found that only for one of the five selected indicators is the possibility estimated to achieve by 2030 the average level of performance in EU countries, which represents a degree of implementation of only $20 \%$.

Regarding the possible recommendations that could accelerate the achievement of the SDGs, there are a multitude of specific approaches, but no general recommendations that have immediate effects. For example, with regard to SDG 1 and SDG 7, especially in the current context of the bursting of energy prices across Europe, support programs for vulnerable consumers should be introduced, consisting of targeted aid to fully or partially compensate the increases in the price of electricity. Thus, a synergistic effect would be generated, limiting the at-risk-of-poverty rate, while limiting the negative effects on the percentage of the population unable to keep home adequately warm.

To accelerate the achievement of SDG 2 targets, extensive processes of restructuring the production structures in agriculture and the processing industry are needed. The use of digital technologies in agriculture has been shown to have significant effects, especially by optimizing production processes and reducing the overuse of substances harmful to the environment and human health, positively affecting SDG 6 targets. Moreover, investments in innovation and research can contribute substantially to achieving the specific targets of SDG 2, but also SDG 9.

Education is a prerequisite for achieving all UN SDGs. Education in Bulgaria is free and compulsory from 5 to 16 years of age, but the estimated results in terms of reaching the targets for 2030 are not very encouraging. There is a need for a considerable improvement in students' achievements in reading, mathematics, and science. Moreover, significant challenges remain for children from vulnerable groups; the school failing to compensate for social inequalities and poverty is perpetuated from one generation to the next. There is a need for deep reforms and a new approach in terms of school and also vocational education and training.

Achieving gender equality is another SDG for which Bulgaria has minimal chances to reach the proposed targets for 2030. The Bulgarian legislation guarantees full gender equality in all aspects of social, economic, and political life. More consistent efforts must be made to meet the highest international standards in the fields of health, employment, and education, improving the life development of the socially weak and vulnerable groups of society. More measures need to be taken as a matter of priority to encourage women's participation in the labor market, reduce gender disparities in pay or participation in decision-making, or combat gender-based violence.

Regarding SDG 8, a major issue is the reduction in the rate of demographic replacement caused by the intensive emigration process of working age people and the aging of the labor force, amplified by the negative natural growth of the population, while regional disparities in the social and economic development of the country are increasing. Administrative and financial incentives must be implemented and supported urgently, especially in regions with the highest unemployment, as well as in high-tech industries and services. Measures are also needed to increase the general labor force potential through lifelong learning and through active engaging of the elderly who continue to work.

The apparent lack of performance is mainly due to the significant differences existing in the base period (2015) between Bulgaria and the rest of the European countries, but also to the dynamic differential of the evolution of these indicators until 2030. Even if the trends in Bulgaria and Member States are convergent, the difference in dynamics prevents Bulgaria from showing higher performance. However, it should be noted that the country is on a positive, European trajectory, and with a higher degree of involvement from a political, financial, and social point of view, performance will not be long in coming (Table 18). 


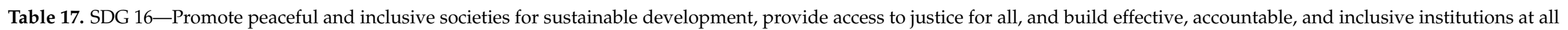
levels.

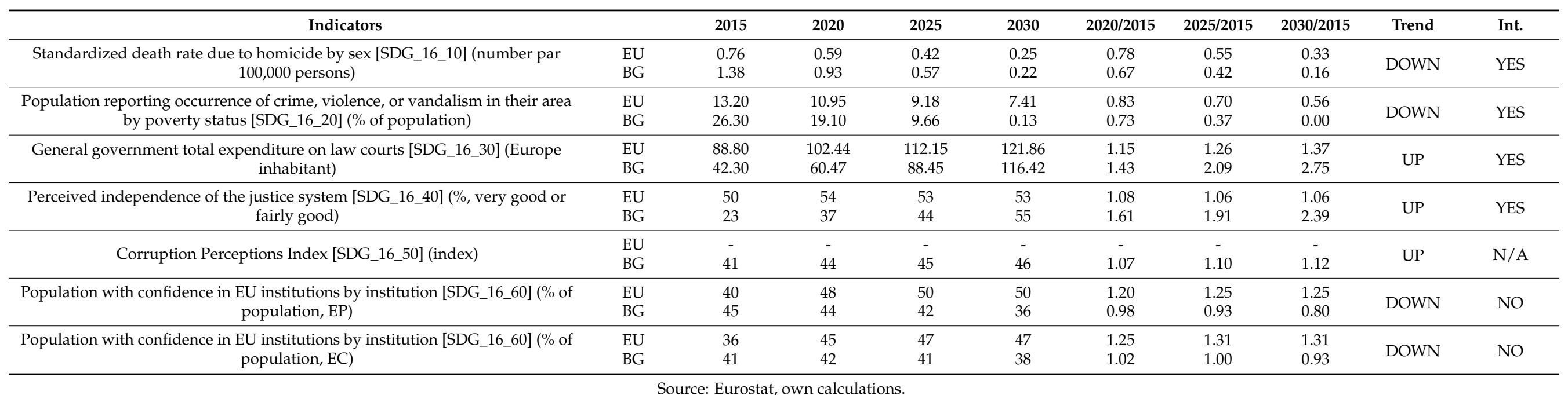

Table 18. SDG 17-Strengthen the means of implementation and revitalize the global partnership for sustainable development.

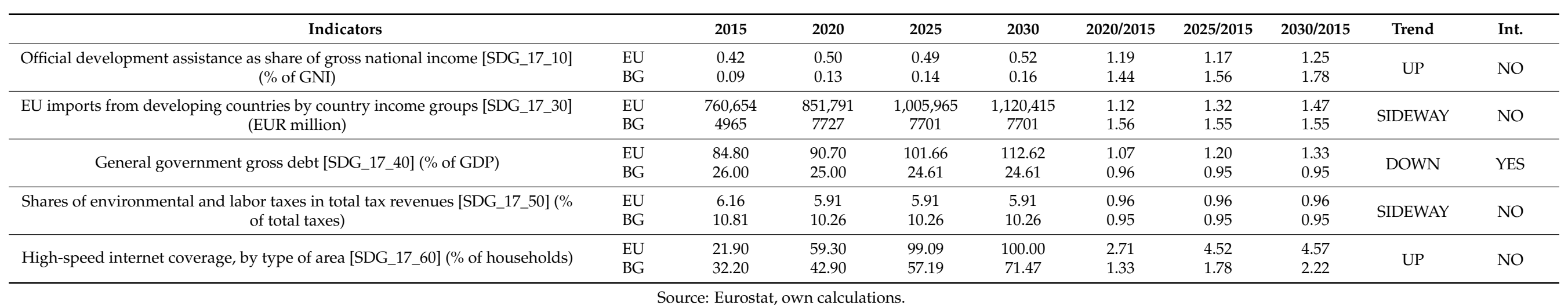




\section{Conclusions}

The importance of defining and fulfilling the objectives assumed by the 2030 Agenda for sustainable development is crucial, both for the progress of contemporary society and for offering a chance to future generations.

Our research started from the need to obtain an overview of the existing situation in Bulgaria in terms of assessment of SDGs implementation, given the paucity of information on this topic. Moreover, through our research we wanted to evaluate the potential for sustainable development in terms of the ability to achieve the targets for specific SDG indicators.

In order to fulfill the proposed goal, the research approached both the trend and the dynamics of the evolution of the indicators selected for the analysis, with the help of dynamic indices and a time series analysis based on ARIMA methodology. The data provided by Eurostat for the SDG indicators were considered, starting with 2007 until the most recent available value. Given the fact that there are few quantitative targets, we preferred to compare Bulgaria's performance with the average of similar indicators at EU level, in order to have a measure of progress.

The results obtained from the study are encouraging and prove the existence of high potential in terms of sustainable development of Bulgaria, with the absolutely necessary condition to continue the projects started in this field and, where there is a differential of dynamics compared to the evolution of indicators, at EU level, to increase political, financial, and administrative efforts to achieve positive results.

In the case of most indicators, the difference in development compared to the rest of the Member States is absolutely obvious for the period considered as the basis for assessing the progress, respectively 2015, from which the SDGs were adopted. There were many indicators for which the trend they registered is the positive one, similar to the trend registered at EU level, but the estimated evolution of the dynamics of the evolution of indicators is not enough to reach the EU average by 2030, requiring an acceleration of the transition to a green and sustainable economy, especially in the context of the growth of European ambitions in terms of the transition to a zero carbon economy.

The general estimated degree of achievement of the SDG in Bulgaria is only $36.28 \%$, respectively; for the 113 indicators considered in the analysis there is a reasonable forecast that 41 of them will reach or exceed the average value recorded at EU level; for none of the 17 SDGs not being registered is there a percentage of $100 \%$ fulfillment. The results of the research suggest that there are SDGs for which there is a satisfactory degree of performance (SDG 6, SDG 15, SDG 16), but there are also SDGs for which much greater attention and involvement is needed from stakeholders to support and accelerate the reaching of the proposed targets (SDG 2, SDG 4, SDG 5, SDG 7, SDG 10).

Comparing the results obtained in Bulgaria with the results of more recent research published for the neighboring country, Romania, we observe a very similar degree of development and forecast of SDG compliance, respectively, 37.38\% for Romania compared to $36.28 \%$ for Bulgaria [63].

For a comparison of Bulgaria's performance with more economically developed countries in Europe, a study published on the implementation of the 2030 Agenda in Spain mentions for the 2030 Horizon a percentage of reaching the SDG targets of $42.20 \%$ [64]. Similarly, in a recently published research, the percentage of achievement of SDG targets in Italy was analyzed and discussed, and the result is very close to that recorded in Spain, respectively $41.67 \%$ [65]. As can be seen, according to published research, the estimated percentage of meeting the targets assumed by implementing the 17 SDGs varies between $37 \%$ and $42 \%$, which demonstrates a certain uniformity of performance at the national level.

The efforts needed to sustain the sustainable development of the economy and society, as well as for the most efficient and rapid transition to a low-carbon economy, are clearly consistent and require significant involvement of all stakeholders to maintain at least the 
current pace of progress, not to mention accelerating the pace. The European Union is deeply concerned about the transition to a low-carbon economy, providing the muchneeded political and financial support for this process, but it also needs the political and social will at the level of each Member State to benefit from EU support and implement change towards a more sustainable and inclusive economy and society.

Moreover, there is a need for greater involvement on the part of researchers in terms of assessing the current state and potential for progress in the transition to a sustainable society, due to the huge volume of data needed to adopt the most effective action decisions considered with the evaluation of the associated direct and indirect effects.

The results of this empirical research should also be analyzed, taking into account the potential limitations they imply. A potential constraint of this research is represented by the availability of the data and the methodological framework. The findings of this research could generate future research directions, providing the data needed to develop sectoral models in terms of analyzing the effectiveness of SDG implementation or ways to assess the effects of various public policies or economic or social measures that have been adopted or are being considered for implementation, with the ultimate goal of developing a more sustainable and inclusive human society.

Author Contributions: Conceptualization, G.H.I. and I.C.P.; methodology, G.H.I., E.J. and F.G.; supervision, G.H.I., I.C.P. and D.I.; writing-original draft, G.H.I.; writing-review and editing, G.H.I., E.J., I.C.P., F.G., L.T. and D.I. All authors have read and agreed to the published version of the manuscript.

Funding: This research received no external funding.

Institutional Review Board Statement: Not applicable.

Informed Consent Statement: Not applicable.

Data Availability Statement: Not applicable.

Conflicts of Interest: The authors declare no conflict of interest.

\section{References}

1. United Nations. Transforming Our World: The 2030 Agenda for Sustainable Development. 2015. Available online: https: //sustainabledevelopment.un.org/post2015/transformingourworld/publication (accessed on 10 September 2021).

2. United Nations. Voluntary National Review Sustainable Development Goals Bulgaria. 2020. Available online: https:// sustainabledevelopment.un.org/content/documents/26289VNR_2020_Bulgaria_Report.pdf (accessed on 10 September 2021).

3. Guijarro, F.; Poyatos, J.A. Designing a Sustainable Development Goal Index through a Goal Programming Model: The Case of EU-28 Countries. Sustainability 2018, 10, 3167. [CrossRef]

4. Bulgarian Platform for International Development. The Link between the Implementation of the UN Sustainable Development Goals in Bulgaria and the Migration-Monitoring Report. 2020. Available online: https://gcap.global/wp-content/uploads/2021 /02/Monitoring-report-2020-BPID.pdf (accessed on 10 September 2021).

5. Stanujkic, D.; Popovic, G.; Zavadskas, E.K.; Karabasevic, D.; Binkyte-Veliene, A. Assessment of Progress towards Achieving Sustainable Development Goals of the "Agenda 2030" by Using the CoCoSo and the Shannon Entropy Methods: The Case of the EU Countries. Sustainability 2020, 12, 5717. [CrossRef]

6. Eurostat. SDG Indicators: Goal by Goal. 2021. Available online: https:/ / ec.europa.eu/eurostat/web/sdi/indicators (accessed on 5 September 2021).

7. Jeliazkova, M.; Minev, D.; Draganov, D. Assessing Youth Employment Policies in 28 European Countries; EXCEPT Working Papers, WP No. 55; Tallinn University: Tallinn, Estonia, 2018.

8. Kandilarov, E. Bulgaria Social Briefing: A New Data for the Bulgarian Poverty and Social Inclusion; China-CEE Institute: Budapest, Hungary, 2021; Volume 40, pp. 1-6.

9. Jeliazkova, M.; Minev, D. Bulgaria: Poverty Watch 2020, European Anti Poverty Network. 2020. Available online: https: //www.eapn.eu/wp-content/uploads/2020/10/EAPN-EAPN-Bulgaria-Poverty-Watch-2020_ENG-4747.pdf (accessed on 12 September 2021).

10. Petrova, S. Influence of the Specialisation of the Agricultural Production on the Assortment Supply. In Proceedings of the International Scientific and Practical Conference "State and Problems in the Management and Development of Agriculture", D.A. Tsenov Academy of Economics, Svishtov, Bulgaria, 4 October 2019; pp. 278-279.

11. Sachs, J.; Schmidt-Traub, G.; Kroll, C.; Lafortune, G.; Fuller, G.; Woelm, F. The Sustainable Development Goals and COVID-19. In Sustainable Development Report 2020; Cambridge University Press: Cambridge, UK, 2020. 
12. World Health Organization. Bulgaria: Profile of Health and Well-Being. 2017. Available online: https://www.euro.who.int/_ data/assets/pdf_file/0003/354036/214827_WHO_BULGARIA_PROFILE_EN.pdf (accessed on 12 September 2021).

13. Ionescu, G.H.; Firoiu, D.; Tănasie, A.; Sorin, T.; Pîrvu, R.; Manta, A. Assessing the Achievement of the SDG Targets for Health and Well-Being at EU Level by 2030. Sustainability 2020, 12, 5829. [CrossRef]

14. Mitev, P.-E.; Popivanov, B.; Kovacheva, S.; Simeonov, P. Youth Study Bulgaria 2018/2019; Friedrich-Ebert-Stiftung e. V. Referat Mittel-und Osteuropa: Berlin, Germany, 2019.

15. Bulgarian Gender Research Foundation (BGRF) and Bulgarian Social Watch Coalition. Implementing the SDGs-from Discussions to Strategies and Reforms. 2017. Available online: https:/ / www.socialwatch.org/sites/default/files/2017-SR-BULGARIA-eng. pdf (accessed on 11 September 2021).

16. Terziev, V.; Lyubcheva, M.; Mihailova, K. The Necessity of Changes in the Higher Education in Bulgaria. In Proceedings of the INTCESS 2021 8th International Conference on Education and Education of Social Sciences, Virtual Conference, 18-19 January 2021; pp. 646-657.

17. Dobbins, M.; Leišyte, L. Analysing the Transformation of Higher Education Governance in Bulgaria and Lithuania. Public Manag. Rev. 2014, 16, 987-1010. [CrossRef]

18. World Bank Group. Bulgaria's Potential for Sustainable Growth and Shared Prosperity. 2015. Available online: https://elibrary. worldbank.org/doi/pdf/10.1596/23116 (accessed on 10 September 2021).

19. Deimel, J.; Schubert, G. (Eds.) Women in the Balkans/Southeastern Europe; Suedosteuropa Studien 79; Biblion Media Publ.: Zurich, Switzerland, 2016; pp. 89-105.

20. Stoilova, M. Mind the Gap: The Changing Face of Gender (In) Equality in Bulgaria after 1989. In Gender (in) Equality and Gender Politics in Southeastern Europe; Hassenstab, C.M., Ramet, S.P., Eds.; Gender and Politics; Palgrave Macmillan: London, UK, 2015.

21. European Institute for Gender Equiality. Gender Equality Index 2019: Bulgaria. 2019. Available online: https:/ / eige.europa.eu/ sites/default/files/documents/20190385_mh0419035enn_pdf.pdf (accessed on 10 September 2021).

22. National Statistical Institute. 2021. Available online: https:/ /nsi.bg/en (accessed on 10 September 2021).

23. Kastchiev, I. Control and Regulation of Water and Sanitation (WS) Services in Bulgaria: Effect on Quality and Efficiency. In The Political Economy of Local Regulation; Asquer, A., Becchis, F., Russolillo, D., Eds.; Studies in the Political Economy of Public Policy; Palgrave Macmillan: London, UK, 2017.

24. Braig, K.F. The European Court of Human Rights and the right to clean water and sanitation. Water Policy 2018, 20, 282-307. [CrossRef]

25. Ministry of Environment and Water. National Strategy for Management and Development of the Water Sector in Bulgaria. 2012. Available online: https://www.moew.government.bg/bg/vodi/strategicheski-dokumenti/nacionalna-strategiya-za-upravleniei-razvitie-na-vodniya-sektor-v-republika-bulgariya / (accessed on 10 September 2021).

26. Andreas, J.-J.; Burns, C.; Touza, J. Overcoming energy injustice? Bulgaria's renewable energy transition in times of crisis. Energy Res. Soc. Sci. 2018, 42, 44-52. [CrossRef]

27. Mastropietro, P. Who should pay to support renewable electricity? Exploring regressive impacts, energy poverty and tariff equity. Energy Res. Soc. Sci. 2019, 56, 101222. [CrossRef]

28. Florea, N.M.; Bădîrcea, R.M.; Pîrvu, R.C.; Manta, A.G.; Doran, M.D.; Jianu, E. The impact of agriculture and renewable energy on climate change in Central and East European Countries. Agric. Econ. 2020, 66, 444-457. [CrossRef]

29. Manta, A.G.; Florea, N.M.; Bădîrcea, R.M.; Popescu, J.; Cîrciumaru, D.; Doran, M.D. The Nexus between Carbon Emissions, Energy Use, Economic Growth and Financial Development: Evidence from Central and Eastern European Countries. Sustainability 2020, 12, 7747. [CrossRef]

30. Włodarczyk, B.; Firoiu, D.; Ionescu, G.H.; Ghiocel, F.; Szturo, M.; Markowski, L. Assessing the Sustainable Development and Renewable Energy Sources Relationship in EU Countries. Energies 2021, 14, 2323. [CrossRef]

31. Terziev, P.; Shishkova, M. State and opportunities for achieving sustainable economic growth and productive employment in rural areas of Bulgaria. Sci. Work. Agrar. Univ.-Plovdiv 2018, 61, 105-113.

32. Mitra, P.; Pouvelle, C. Productivity Growth and Structural Reform in Bulgaria: Restarting the Convergence Engine; IMF Working Paper, WP/12/131; International Monetary Fund: Washington, DC, USA, 2012.

33. Barrientos, S.; Mayer, F.; Pickles, J.; Posthuma, A. Decent work in global production networks: Framing the policy debate. Int. Labour Rev. 2011, 150, 297-317. [CrossRef]

34. Băndoi, A.; Jianu, E.; Enescu, M.; Axinte, G.; Tudor, S.; Firoiu, D. The Relationship between Development of Tourism, Quality of Life and Sustainable Performance in EU Countries. Sustainability 2020, 12, 1628. [CrossRef]

35. Cismas, L.M.; Miculescu, A.; Negrut, L.; Negrut, V.; Otil, M.D.; Vadasan, I. Social capital, social responsibility, economic behavior and sustainable economic development-An analysis of Romania's situation. Transform. Bus. Econ. 2019, 18, 605-628.

36. Dutta, S.; Escalona Reynoso, R.; Garanasvili, A.; Guadagno, F.; Hardman, C.; Lanvin, B.; Rivera Leon, L.; Wunsch-Vincent, S. The Future of Medical Innovation [Chapter 1]. In Global Innovation Index 2019: Creating Healthy Lives; Dutta, S., Lanvin, B., Wunsch-Vincent, S., Eds.; Cornell, INSEAD, and WIPO: Ithaca, NY, USA; Fontainebleau, France; Geneva, Switzerland, 2019.

37. Hingley, P.; Park, W.G. Do business cycles affect patenting? Evidence from European Patent Office filings. Technol. Forecast. Soc. Chang. 2017, 116, 76-86. [CrossRef]

38. Ionescu, G.H.; Firoiu, D.; Pîrvu, R.; Enescu, M.; Rădoi, M.-I.; Cojocaru, T.M. The Potential for Innovation and Entrepreneurship in EU Countries in the Context of Sustainable Development. Sustainability 2020, 12, 7250. [CrossRef] 
39. Ilieva-Trichkova, P.; Boyadjieva, P. Dynamics of inequalities in access to higher education: Bulgaria in a comparative perspective. Eur. J. High. Educ. 2014, 4, 97-117. [CrossRef]

40. Tochkov, K.; Nenovsky, N.; Tochkov, K. University efficiency and public funding for higher education in Bulgaria. Post-Communist Econ. 2012, 24, 517-534. [CrossRef]

41. Nonchev, A.; Encheva, S.; Atanassov, A. Social Inequalities and Variations in Tolerance toward Immigrants. Int. J. Soc. 2012, 42, 77-103. [CrossRef]

42. Șerbanică, C.; Constantin, D.-L. Sustainable cities in central and eastern European countries. Moving towards smart specialization. Habitat Int. 2017, 68, 55-63. [CrossRef]

43. Greene, M.; Mora, R.; Figueroa, C.; Waintrub, N.; Ortúzar, J. Towards a sustainable city: Applying urban renewal incentives according to the social and urban characteristics of the area. Habitat Int. 2017, 68, 15-23. [CrossRef]

44. Terziev, V.; Arabska, E. Sustainable Rural Development through Organic Production and Community-Supported Agriculture in Bulgaria. Bulg. J. Agric. Sc. 2016, 22, 527-535.

45. Polido, A.; Moreno Pires, S.; Rodrigues, C.; Teles, F. Sustainable development discourse in Smart Specialization Strategies. J. Clean. Prod. 2019, 240, 118224. [CrossRef]

46. Simeonov, S.; Stefanova, M. Corporate Social Responsibility in Bulgaria: The Current State of the Field. In Corporate Social Responsibility in Europe; Idowu, S., Schmidpeter, R., Fifka, M., Eds.; CSR, Sustainability, Ethics \& Governance; Springer: Cham, Switzerland, 2015.

47. Bancheva-Preslavska, H.; Dallmer, J. Alternative Urban Eco Tours for Responsible Consumption and Sustainability-The Example of Bulgaria. Eur. J. Sustain. Dev. 2020, 9, 416-424. [CrossRef]

48. Liobikienè, G.; Dagiliūtè, R. The relationship between economic and carbon footprint changes in EU: The achievements of the EU sustainable consumption and production policy implementation. Environ. Sci. Policy 2016, 61, 204-211. [CrossRef]

49. Buchner, B.; Brown, J.; Corfee-Morlot, J. Monitoring and Tracking Long-Term Finance to Support Climate Action. In OECD/IEA Climate Change Expert Group Papers; No. 2011/03; OECD Publishing: Paris, France, 2011.

50. Ministry of Environment and Water. Draft Strategy for Sustainable Use of the Black Sea Coastal Ecosystems. 2016. Available online: https:/ / species.bluelink.net/wp-content/uploads/2017/06/Strategy-SPECIES-ENG.pdf (accessed on 10 September 2021).

51. Koulov, B. Sustainable environmental management of marine regions: The Black Sea case study. Geoadria 2012, 17, 3-11. [CrossRef]

52. European Commission. Climate Change Adaptation of Major Infrastructure Projects. Country Report for Bulgaria. 2018. Available online: http:/ / publications.europa.eu/resource/cellar/ff093f0f-034a-11e9-adde-01aa75ed71a1.0001.01/DOC_1 (accessed on 10 September 2021).

53. European Commission. The EU Environmental Implementation Review 2019. Country Report-Bulgaria. 2019. Available online: https: / / ec.europa.eu/environment/eir/pdf/report_bg_en.pdf (accessed on 10 September 2021).

54. National Commission for Combating Trafficking in Human Beings. Annual Report for the Implementation of the 2018 National Programme for Combating Trafficking in Human Beings and Protection of Victims. 2018. Available online: https: / /antitraffic. government.bg/uploads/Reports/EN/2018_Annual_report_ENG.docx (accessed on 11 September 2021).

55. European Commission. Country Report Bulgaria 2019 Including an In-Depth Review on the Prevention and Correction of Macroeconomic Imbalances. 2019. Available online: https:/ / op.europa.eu/en/publication-detail/-/publication/a56dd9c1-3b6b11e9-8d04-01aa75ed71a1 (accessed on 11 September 2021).

56. Box, G.; Jennkins, G.; Reinsel, G.; Ljung, G. Time Series Analysis: Forecasting and Control, 5th ed.; John Wiley \& Sons: Hoboken, NJ, USA, 2016.

57. Anghelache, C.; Manole, A. Dynamic/chronological (time) series-Theoretical presentation, structure, relationships between indices. Roman. Stat. Rev. 2012, 10, 78-87.

58. Baltac, A. Economic and Financial Analysis Based on Time Series Method. Int. J. Acad. Res. Account. Financ. Manag. Sci. 2015, 5, 77-82. [CrossRef]

59. Box, G.E.P.; Jenkin, G.M. Time Series of Analysis, Forecasting and Control; Holden-Day: San Franscico, CA, USA, 1976.

60. Box, G.E.P.; Jenkins, G.M.; Reinsel, G.C. Time Series Analysis, Forecasting and Control, 3rd ed.; Prentice Hall: Englewood Clifs, NJ, USA, 1994.

61. Abraham, B.; Ledolter, J. Statistical Methods for Forecasting; Wiley: New York, NY, USA, 1983.

62. Brockwell, P.J.; Davis, R.A. Introduction to Time Series and Forecasting, 2nd ed.; Springer: Berlin/Heidelberg, Germany, 2002.

63. Firoiu, D.; Ionescu, G.H.; Băndoi, A.; Florea, N.M.; Jianu, E. Achieving Sustainable Development Goals (SDG): Implementation of the 2030 Agenda in Romania. Sustainability 2019, 11, 2156. [CrossRef]

64. Boto-Álvarez, A.; García-Fernández, R. Implementation of the 2030 Agenda Sustainable Development Goals in Spain. Sustainability 2020, 12, 2546. [CrossRef]

65. Dello Strologo, A.; D'Andrassi, E.; Paoloni, N.; Mattei, G. Italy versus Other European Countries: Sustainable Development Goals, Policies and Future Hypothetical Results. Sustainability 2021, 13, 3417. [CrossRef] 